\title{
Fascioliasis in Llama, Lama glama, in Andean Endemic Areas: Experimental Transmission Capacity by the High Altitude Snail Vector Galba truncatula and Epidemiological Analysis of Its Reservoir Role
}

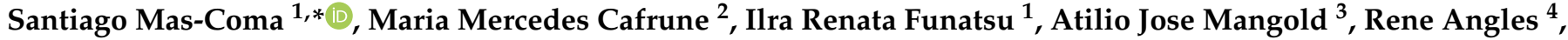 \\ Paola Buchon ${ }^{5}$, Maria Cecilia Fantozzi ${ }^{1}$, Patricio Artigas ${ }^{1}$ (D), Maria Adela Valero ${ }^{1}$ (I) \\ and Maria Dolores Bargues $1, *$ (1)
}

Citation: Mas-Coma, S.; Cafrune, M.M.; Funatsu, I.R.; Mangold, A.J.; Angles, R.; Buchon, P.; Fantozzi, M.C.; Artigas, P.; Valero, M.A.; Bargues, M.D. Fascioliasis in Llama, Lama glama, in Andean Endemic Areas: Experimental Transmission Capacity by the High Altitude Snail Vector Galba truncatula and Epidemiological Analysis of Its Reservoir Role. Animals 2021, 11, 2693. https:// doi.org/10.3390/ani11092693

Academic Editor:

Javier González-Miguel

Received: 15 July 2021

Accepted: 2 September 2021

Published: 14 September 2021

Publisher's Note: MDPI stays neutral with regard to jurisdictional claims in published maps and institutional affiliations.

Copyright: (c) 2021 by the authors. Licensee MDPI, Basel, Switzerland. This article is an open access article distributed under the terms and conditions of the Creative Commons Attribution (CC BY) license (https:// creativecommons.org/licenses/by/ $4.0 /)$.
1 Departamento de Parasitologia, Facultad de Farmacia, Universidad de Valencia, Av. Vicent Andres Estelles s/n, 46100 Burjassot, Valencia, Spain; Ilra.Funatsu@uv.es (I.R.F.); cfantozzi@fcv.unl.edu.ar (M.C.F.); Patricio.Artigas@uv.es (P.A.); Madela.Valero@uv.es (M.A.V.)

2 Instituto de Investigación Animal del Chaco Semiárido, Área de Investigación en Salud Animal, Estación Experimental Agropecuaria Salta, Instituto Nacional de Tecnología Agropecuaria (INTA), Ministerio de Agricultura, Ganadería y Pesca CIAP, Ruta Nacional 68-km 172, Cerrillos A4403, Salta, Argentina; cafrune.wierna@inta.gob.ar

3 Estación Experimental Agropecuaria Rafaela, Instituto Nacional de Tecnologia Agropecuaria (INTA), Ministerio de Agricultura, Ganadería y Pesca, CC 22 INTA Rafaela, Rafaela 2300, Santa Fe, Argentina; mangold.atilio@inta.gob.ar

4 Cátedra de Parasitología, Facultad de Medicina, Universidad Mayor de San Andrés (UMSA), Av. Saavedra, Miraflores, La Paz, Bolivia; anglesrene@hotmail.es

5 Unidad de Limnología, Instituto de Ecología, Universidad Mayor de San Andrés (UMSA), Campus Calle 27, Cota Cota, La Paz, Bolivia; pbuchon31@gmail.com

* Correspondence: S.Mas.Coma@uv.es (S.M.-C.); M.D.Bargues@uv.es (M.D.B.)

Simple Summary: The infection by the liver fluke Fasciola hepatica in South American camelids, mainly llamas and alpacas, has been the focus of many studies. However, their capacity to participate in the transmission of the disease and their potential reservoir role in human or animal endemic areas have never been studied. Therefore, all development stages of an isolate from Argentine llama of the high Andean plateau have been experimentally investigated, from egg embryogenesis to metacercarial infectivity, by using the vector snail Galba truncatula from the high altitude Bolivian Altiplano human hyperendemic area. Although eggs shed by llamas may successfully develop until the adult stage in a subsequent mammal host, the transmission capacity of the llama proved to be pronouncedly less efficient than that of other hosts as sheep and cattle. Moreover, the low prevalences, intensities, and daily fecal outputs of liver fluke eggs in llama in Andean endemic areas, together with their peculiar defecating behavior in dung piles always far from freshwater collections, indicate that the contribution of this camelid should be considered negligible. Therefore, the llama does not need to receive priority within fascioliasis control initiatives, although it may play a disease-spreading role if used as a pack animal.

Abstract: South American camelids are definitive hosts of Fasciola hepatica. However, their capacity to participate in the transmission and epidemiology of fascioliasis has never been appropriately studied. Therefore, an F. hepatica isolate from Argentine llama is for the first time analyzed using Galba truncatula lymnaeids from Bolivia. Experimental follow-up studies included egg embryogenesis, miracidial infection of lymnaeid snails, intramolluscan larval development, cercarial production, chronobiology of cercarial shedding, vector survival to infection, and metacercarial infectivity of mammal host. Shorter prepatent and patent periods were leading to markedly lower cercarial production, shorter cercarial shedding, and a higher negative impact on snail survival. The usually low liver fluke prevalences and intensities and low daily fecal outputs indicate that llamas do not substantially contribute to fascioliasis transmission. The defecating behavior in dung piles far from freshwater collections prevents lymnaeid infection by eggs shed by this camelid. All results suggest 
the reservoir role of the llama to be negligible and, therefore, no priority within control measures in endemic areas. However, llamas may play a disease-spreading role if used as pack animals in rural areas. In the Northern Bolivian Altiplano human hyperendemic area, neither llamas nor alpacas should be considered for control measures within a One Health action.

Keywords: Andean fascioliasis endemic areas; llama; Fasciola hepatica; Galba truncatula; experimental transmission; field epidemiology; reservoir role; Argentina; Bolivia

\section{Introduction}

The two trematode species Fasciola hepatica and F. gigantica are transmitted by freshwater gastropod snails of the family Lymnaeidae and cause a parasitic disease affecting domestic and sylvatic mammals, as well as humans. Fascioliasis is a highly pathogenic disease with a large economic impact on husbandry of livestock in different countries $[1,2]$ as well as globally, including countries where human infection by these fasciolids is a wide health problem [3]. An estimation of total world economic losses in only cattle and buffalo reached USD 3.2 billion [4].

In humans, fascioliasis may also be highly pathogenic and include severe clinical pictures [5-7] and sequelae [5,8]. In areas where it is endemic in humans, it may cause community underdevelopment $[9,10]$, as is the case of many rural areas of developing countries where the immune suppression it causes [11] underlies very frequent coinfections with other pathogenic parasites [12,13] and microorganisms [14,15]. Moreover, the transmission and epidemiology of this disease have proved to be strongly influenced by climate change $[16,17]$ and also by global change aspects such as anthropogenic modifications of the environment, man-made movements of domestic ruminants, and livestock importation and exportation between countries, and even continents [18].

The description of several human endemic areas in different continents, where infection may occur very early in life [19], and the increasing number of reports on fasciolid infected patients throughout, not only in low-income countries but also in developed countries [20], led the World Health Organization to include this disease among the group of food-borne trematodiases within the list of Neglected Tropical Diseases (NTDs) [21]. Within this framework, the WHO launched a worldwide strategy of preventive chemotherapy based on the availability of a very efficient drug for human treatment, triclabendazole [22]. The programs of control were designed according to the different human endemic countries depending on the characteristics of their patterns of transmission and their epidemiological scenarios. Strengthening these programs is key in the new NTD road map 2030 of the WHO, in the way for the sustainability of the health systems [23].

In South America, F. hepatica is the causal agent of many human fascioliasis endemic areas, which are mainly distributed in altiplanos and valleys at high altitudes in the Andean region. In these areas, the aforementioned preventive chemotherapy strategy is now being complemented by One Health interventions to decrease the risks of infection and reinfection. Control measures implemented within these interventions include the assessment of the contributions of the different livestock reservoir species to the transmission and epidemiology of the disease [24-26], among many other action axes [27-29].

The present study focuses on the potential role of South American camelids in the transmission and epidemiology of the disease in the very high altitude Andean endemic area. Indeed, infection by F. hepatica has been reported in the four species of South American camelids, namely the domesticated llama (Lama glama) and alpaca (Lama pacos), and the sylvatic but also semi-captive vicuña (Vicugna vicugna) and guanaco (Lama guanicoe). However, their capacity to transmit fascioliasis has never been evaluated.

These camelids grow in herds throughout the Andean mountains in altitudes higher than $2500 \mathrm{~m}$ where they are well adapted to the extreme conditions of this environment. The husbandry of llamas and alpacas has been traditionally implemented for meat and 
milk production, as well as for their use as pack animals in rural areas. More recently, their interest has been increased in the fur industry because of the quality of their wool and the countries have therefore launched initiatives to improve their husbandry, among which control measures against their infectious diseases [30].

The aforementioned reports in South American camelids concern the Andean countries where the most public health important human fascioliasis endemic areas are known to be present, mainly in high or very high altitude areas:

- in Argentina, there is the risk of human infection in several provinces and human endemic areas that has been described [31-33]; F. hepatica infection reports in South American camelids of this country concern llama [34], vicuña [35,36], and guanaco [37,38];

- $\quad$ in Chile, F. hepatica infected patients have been repeatedly reported from different political regions, including areas presenting human endemicity [39,40]; llamas and alpacas have been reported to be infected by the liver fluke in this country [41];

- in Bolivia, the human fascioliasis hyperendemic area where the highest prevalences (up to $72 \%$ by coprology and $100 \%$ by serology) and intensities (up to 8,000 eggs per gram of feces-epg - in children) have been reported in the Northern Bolivian Altiplano, at 3800-4100 m a.s.l., in between Lake Titicaca and the city of El Alto and the capital La Paz [12,42,43]; F. hepatica infection has been reported in alpacas raised on a farm of Belen, northward of the human endemic area [44,45];

- in Peru, human fascioliasis endemic areas have been described throughout many valleys along the whole north-south distributed Andean chain [13,46-53] and also in the Peruvian Altiplano [54]; the camelid species having been found infected by the liver fluke in Peru include the llama [55,56], alpaca [56-59], and vicuña [60,61].

Most of these reports on liver fluke infection of camelids concern animal endemic areas, but the reports in the Mantaro valley [56] and in the province of Huancavelica [60] refer to human endemic areas in Peru $[46,47,49]$. The report in the Northern Bolivian Altiplano refers to a farm located close to the human hyperendemic area [44,45].

In trematodiases, for a host species to act as a reservoir of the disease the capacity of the adult parasite to develop in this definitive host is not sufficient. It should be experimentally verified that this host participates in the transmission of the parasite. For such a purpose, the whole life cycle of the parasite through and after the involvement of this host should be followed up until the successful infection of a subsequent definitive host. Moreover, surveys in the endemic area should demonstrate that prevalence and intensity rates in this host species are sufficient to assure a stable transmission in the field. For this assessment of transmission capacity and epidemiological involvement in South American camelids, the llama was chosen for the present study. A llama isolate from the Argentine high Andean plateau and the snail vector Galba truncatula from the hyperendemic area of human fascioliasis in the Northern Altiplano of Bolivia were used.

The laboratory studies described herein included the experimental follow-up of all the life cycle phases, comprising the complete development of the egg and miracidium of an F. hepatica isolate obtained in infected llamas from the high Andean plateau of Argentina, the infection of Bolivian G. truncatula vector snail specimens, the development of the larval stages of the liver fluke in this snail up to final production of cercariae, the shedding of cercariae and their chronobiological features, the effects of the infection on the life span of the vector snails, and finally, the infection capacity of the metacercariae in a laboratory model host.

To assess the participation of the llama in the transmission of F. hepatica and its contribution to the epidemiology of the disease, the results obtained in the laboratory and in the field are quantitatively compared with the results previously obtained in the F. hepatica isolates from the two main reservoir species sheep and cattle in the same hyperendemic area of Bolivia [24]. To allow for the obtaining of significant results, the experimental studies undertaken included exactly the same aspects and were made according to identical methods and techniques. Field surveys to assess prevalences, intensities, and egg outputs further help in evaluating the potential role of the host species as a reservoir of the disease. 
Such complete experimental and field studies focus on a South American camelid species for the first time.

A detailed illustration of the complete two-host life cycle of $F$. hepatica is included in Figure 1, showing all the aforementioned aspects assessed for the characterization of the transmission capacity and epidemiological role of the llama from Andean highlands, by comparing with sheep and cattle isolates from the Northern Bolivian Altiplano human hyperendemic high altitude area.

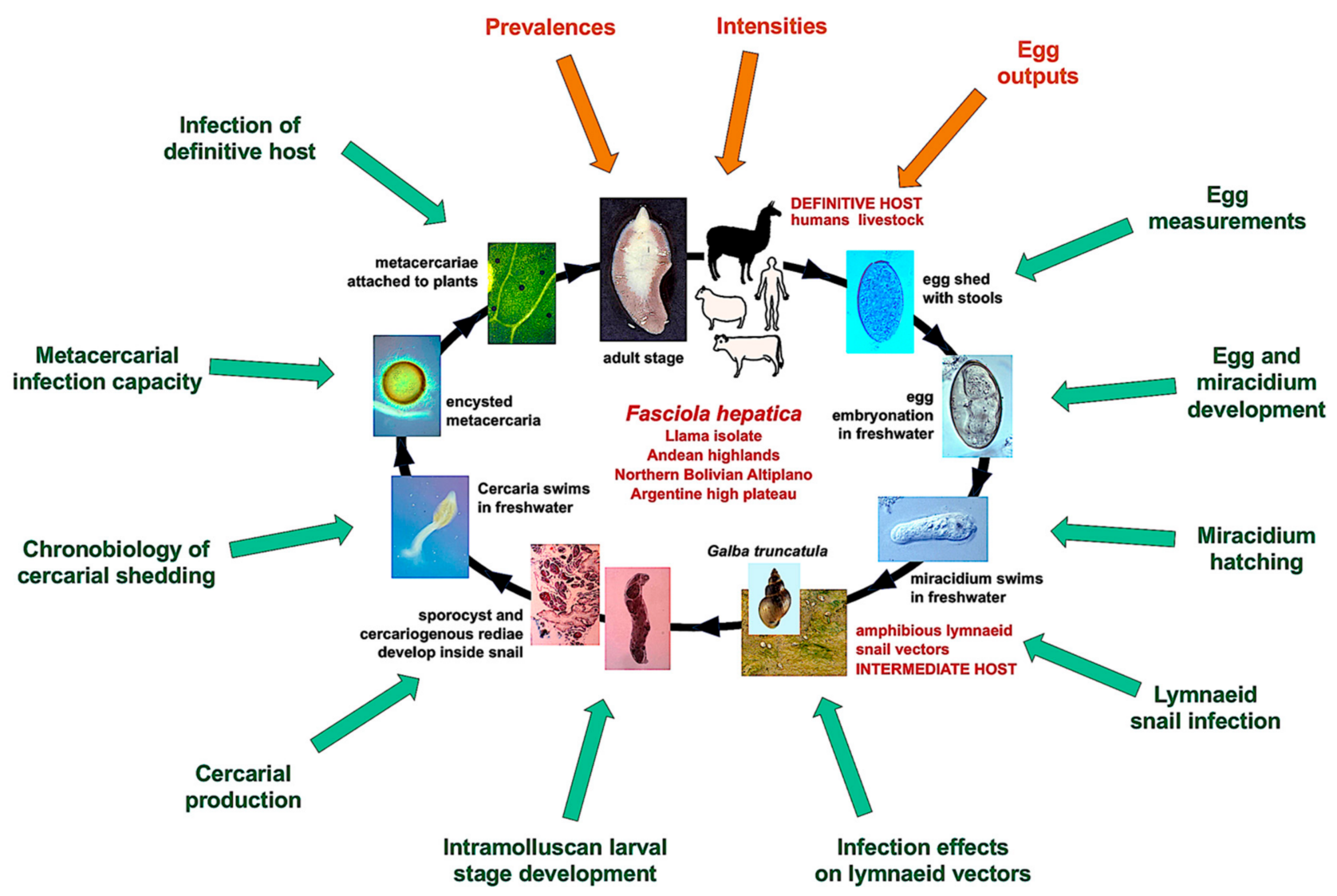

Figure 1. Life cycle of Fasciola hepatica including detailed development phases: Aspects assessed for the characterization of the transmission capacity and epidemiological role of the llama from Andean highlands by comparing with sheep and cattle isolates from the Northern Bolivian Altiplano human hyperendemic area. Green arrows: experimental assessments; brown arrows: field assessments. Schematic drawing by S. Mas-Coma.

\section{Materials and Methods}

\subsection{Fasciolid Materials}

Original $F$. hepatica materials were obtained from livers, bile aspirates, and fecal samples of naturally infected llamas in an area close to the locality of Quichagua $\left(22^{\circ} 48^{\prime} 00.72^{\prime \prime} \mathrm{S}\right.$; $66^{\circ} 01^{\prime} 59.97^{\prime \prime} \mathrm{O}$; altitude of $3586 \mathrm{~m}$ ), located in the Department of Cochinoca, province of Jujuy, Argentine high Andean plateau (Figure 2). This area is an animal fascioliasis endemic area where different species of livestock are infected by the liver fluke [62].

Fluke eggs of llama isolate were obtained from fecal and bile samples. These $F$. hepatica eggs were recovered after isolation by filtration and subsequently shortly maintained in natural water. A temperature of $4{ }^{\circ} \mathrm{C}$ and total darkness were applied until the moment for launching the assessment of the embryogenesis of the eggs.

Lymnaeid snails of the species G. truncatula from the endemic area of the Northern Altiplano were used for the snail vector experimental assays. Fasciola hepatica eggs from llamas were also isolated by filtration of fecal samples and similarly kept until used to obtain miracidia for the experimental infection of the snails. 


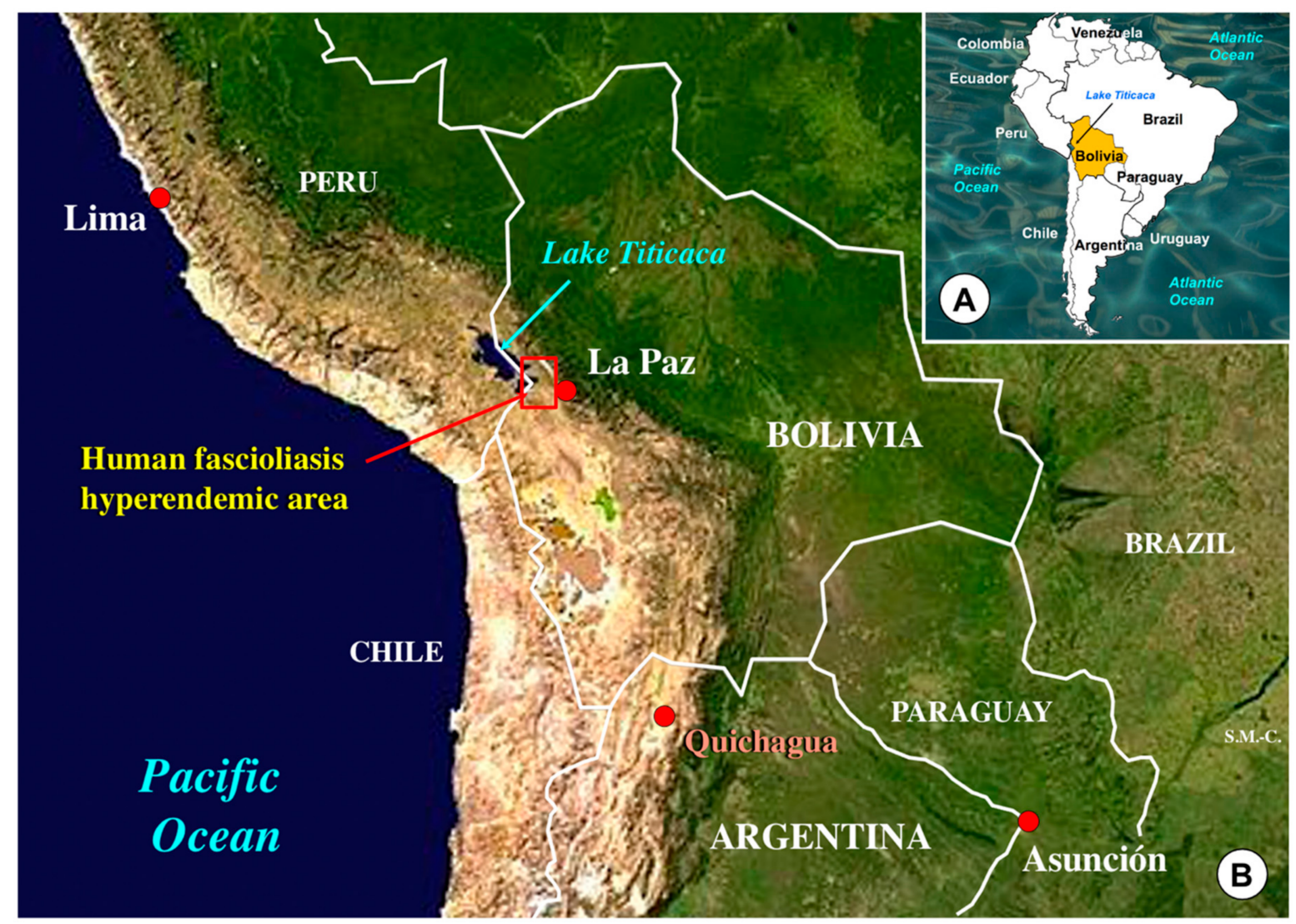

Figure 2. Map showing the locality of Quichagua in the Andean high plateau, at $3586 \mathrm{~m}$ altitude in the North of Argentina where Fasciola hepatica materials were collected from llamas, and the human fascioliasis hyperendemic area, in the Northern Altiplano of Bolivia, at 3820-4100 m altitude, where lymnaeid snail vector specimens of Galba truncatula were collected. Background for (B) from composed satellite map of South America orthographic projection by NASA (full resolution of $1215 \AA$ ̊ 1712 pixels; public domain) via Wikimedia Commons. (A,B), originals S. Mas-Coma.

The Wistar rat served as a laboratory model host to assess the infection of the definitive host. Wistar rat infection was performed with metacercariae of the F. hepatica isolate of the llama. These metacercariae came from the previous infections of the Altiplanic lymnaeid snails and were maintained in natural water at a temperature of $4{ }^{\circ} \mathrm{C}$ in complete darkness. These are standard conditions in experimental work for studies on fasciolid flukes [63].

\subsection{Embryogenesis of Fluke Eggs}

The embryogenesis of eggs was separately studied in eggs collected from feces and in eggs found in bile, following the same procedure. In both cases, the embryogenesis was microscopically followed at a constant temperature of $20{ }^{\circ} \mathrm{C}$ and at time intervals of four days. The different phases of the development of the eggs were considered to assess the embryogenesis, including (i) eggs including a morula, with visible vitelline granules and/or spheroidal cells (E.M.), (ii) eggs including an outlined miracidium, i.e., a miracidial pre-form can already be visualized (E.O.M.), and (iii) eggs including a developed miracidium, i.e., a well defined, completely conformed miracidium is visible (E.D.M). In addition to the eggs in the stages of E.M., E.O.M., and E.D.M., (iv) degenerated eggs (DE), (v) empty eggs (EE), and (vi) broken eggs (BE) were also considered and counted. A total of 33 eggs from each host individual were counted in each 4-day study under the microscope between the slip and coverslip, by distinguishing each egg in which of the aforementioned six phases it was. Appropriate images to illustrate these six stages of the fasciolid eggs have been previously published [25]. Egg counts were noted in percentages independently per each day of observation. For the evaluation of the embryogenesis process, comparisons with the egg embryogenesis curves of the sheep and cattle isolates of F. hepatica from the 
Northern Bolivian Altiplano human hyperendemic area, obtained following the same procedures and from a similar very high altitude [24], were performed.

\subsection{Experimental Infection of Snails}

The lymnaeid species Galba truncatula, a member of the Galba/Fossaria group and considered the most efficient liver fluke vector species [64,65], was selected for the experimental procedures. Laboratory-borne snails derived from G. truncatula population specimens collected in the locality of Ancocagua, at 3,841 m a.s.l., in the Pucarani municipality of the Northern Bolivian Altiplano human hyperendemic area (Figure 2), were used. The genetic characteristics and systematic classification of this population have been previously assessed [28]. Living specimens collected in Ancocagua were transported under isothermal conditions for their laboratory adaptation to standardized controlled conditions of $20{ }^{\circ} \mathrm{C}, 90 \%$ relative humidity (r.h.), and a $12 \mathrm{~h} / 12 \mathrm{~h}$ light/darkness photoperiod in precision climatic chambers (HPS-1500, VB-0714 and HPS-500 models of Heraeus-Vötsch, Calservice Heratec, S.L., Madrid, Spain).

Before the adaptation of the snails to the laboratory, a possible infection by liver flukes acquired in nature was discarded. For this purpose, each snail was maintained in isolation in a small amount of natural water inside a small Petri dish. The presence or absence of moving cercariae or motionless cysts of metacercariae was looked for in each Petri dish under a binocular microscope after a period of $24 \mathrm{~h}$. The non-infected snails were distributed in standard breeding boxes containing $2000 \mathrm{~mL}$ natural freshwater, which was weekly changed. Lettuce and algae were provided as food ad libitum.

Hatching of developed miracidia was forced by putting fully embryonated eggs under light and the miracidia obtained were afterwards used for the experimental infection of snails [66]. The infection susceptibility was assessed in a total of 45 lymnaeid snails of a size of $4.0-5.0 \mathrm{~mm}$. Each snail was exposed to one miracidium for $4 \mathrm{~h}$ in a small Petri dish containing $2 \mathrm{~mL}$ of fresh water. The disappearance of the miracidium was taken as verification of its successful penetration into the snail. The mono-miracidial infection with the $F$. hepatica isolate from llama was carried out under the experimental conditions of $20^{\circ} \mathrm{C} / 20^{\circ} \mathrm{C}$ day / night temperature according to a photoperiod of $12 \mathrm{~h} / 12 \mathrm{~h}$ light/darkness in the aforementioned climatic chambers [67]. For the evaluation of the snail infectivity of the llama isolate, comparisons with the results of the sheep and cattle isolates of $F$. hepatica from the Northern Bolivian Altiplano human hyperendemic area, obtained following the same procedures with the same lymnaeid vector species of the same endemic area and from a similar very high altitude [24], were performed. Characteristics, conditions, and snail number in these infection experiments, together with the aforementioned comparisons, were appropriately noted.

Once the experimental infection was performed, the lymnaeids were again transferred to the $2000 \mathrm{~mL}$ containers and maintained at a permanent temperature of $20{ }^{\circ} \mathrm{C}$, at a relative humidity of $90 \%$, and a light/darkness photoperiod of $12 \mathrm{~h} / 12 \mathrm{~h}$ day/night. Dry lettuce ad libitum was used as food for 30 days. At 30-days post-infection (d.p.i.), the lymnaeid specimens were again individually put in isolation for the daily follow-up of the shedding of cercariae. In each Petri dish, the metacercariae were counted daily for the chronobiological assessment of the cercarial shedding. For both periods of shedding and post-shedding, lettuce was furnished ad libitum to each lymnaeid inside a dish until lymnaeid death.

\subsection{Laboratory Infections of Wistar Rats}

Wistar rats (Iffa Credo, Barcelona, Spain) were used to assess the definitive host infection capacity of the llama $F$. hepatica isolate. A total of 25 Wistar male rats, 4-5 weeks of age, were used as a laboratory mammal model. Previously reported standards were strictly followed, including a commercial diet for these animals (Panlab Chow A04) and natural water ad libitum [68]. 
The experimental infection of the aforementioned Wistar rats was carried out as previously reported [69]. A total of 20 metacercariae was the dose applied for the experimental infection of each rat. A gastric tube was used for the inoculation. Special attention was given to the care and health of the animals. Rat weight and fur appearance were checked weekly in a way to assess the body condition and well-being of the rats by comparing with negative controls. At the end of the experiment, a lower weight was presented by the infected rats. None of the rats died. A necropsy performed at 12 weeks post-infection was undertaken to establish the percentage of rats infected and the intensity or burden concerning the number of flukes obtained in each infected animal. An overdose of a selected anesthetic (IsoFlo; Dr. Esteve SA, Barcelona, Spain) was finally applied to humanely euthanize the animals. The search and collection of flukes were performed by means of a dissecting microscope, following a methodology previously described [15,70]. Flukes were searched first in the bile duct and afterwards throughout the whole liver. All other organs were also analyzed, especially both abdominal and thoracic viscera and cavities, by thoroughly rinsing with water to recover all flukes.

For the evaluation of the definitive host infectivity of the llama isolate, comparisons with the results of the sheep and cattle isolates of F. hepatica from the Northern Bolivian Altiplano human hyperendemic area, obtained with metacercariae recovered following the same procedures with the same lymnaeid vector species of the same endemic area and from a similar very high altitude [24], were performed.

\subsection{Field Surveys of Llamas}

A total of 841 llamas could be coprologically diagnosed, namely 811 llamas from Argentina including 103 from the high Andean plateau of Quichagua and 708 from the provinces of Salta, Jujuy, and Catamarca, and 30 llamas from Bolivia, in the locality of Palcoco in the Northern Altiplano (Figure 2). Fresh fecal samples were immediately placed in a plastic bag, transported to the laboratory within the following $5 \mathrm{~h}$, and maintained at $4{ }^{\circ} \mathrm{C}$ until examination.

Fecal samples from Argentina were processed by a modified technique of flotation [71,72]. The analysis of the samples from Bolivia was performed by means of a modified sedimentation test $[73,74]$. In the samples of both geographical origins, an amount of $4 \mathrm{~g}$ of fecal sample was used to allow for the quantitative analysis. The number of eggs shed by a llama was used to estimate the infection intensity and was expressed in eggs per gram of stools (epg). A host individual was considered negative when no eggs were found in its respective fecal sample after studying three slides.

In Quichagua, the availability of an occasionally slaughtered llama female was additionally used to analyze the liver infection by fasciolids and to further obtain samples of bile aspirates.

Fasciolid eggs found in both feces and bile were used for their size assessment. The fasciolid eggs were measured by means of a computer image analysis system (CIAS). Standardized measurements used were those which have already proved their usefulness in fasciolid trematodes [75]. These measurements were obtained with a digital 3CCD color video camera (Sony DXC-930P, Sony España, S.A., Barcelona, Spain) adapted to a microscope. The captured images were analyzed by means of an image analysis software (ImagePro plus version 5.0 for Windows, Media Cybernetics, Rockville, MD, USA). The characteristics of the fasciolid eggs which were studied comprised the following values: (a) linear measurements including the egg length (EL), egg width (EW), and egg perimeter (EPe); (b) areas including the egg area (EA); and (c) ratios including the EL/EW ratio. The mean and standard deviation plus minimum and maximum values were determined for each measure.

\subsection{Statistical Analyses}

To quantify the participation of the llama to the F. hepatica transmission and to evaluate the reservoir role of this camelid, the results obtained in each aspect were appropriately 
compared with the same results obtained with F. hepatica isolates of sheep and cattle from the hyperendemic area of human fascioliasis in the Northern Altiplano of Bolivia. These two ruminant species have previously been demonstrated to be the main transmitters and reservoirs of the disease in that high altitude area. To assure the significance of these comparisons, the methods and techniques used for the analyses of the Altiplanic sheep and cattle isolates were exactly the same as those used for the llama isolate, regarding experiments in the laboratory as well as surveys in the field [24].

Statistical analyses were performed by applying the SPSS Statistics 26 software. The ANOVA test was employed for the analysis of the data of E.M., E.O.M., E.D.M. in the embryogenesis of the fasciolid eggs. Both the Chi-square test and Yates continuity corrected Chi-square test were utilized for the comparisons of categorical variables. The non-parametric Kruskal-Wallis test was applied for the comparisons of mean data obtained in the experimental infections of both lymnaeid vectors and laboratory rats. The post hoc tests (L.S.D., Student-Newman-Keuls and Duncan's tests) were used for the analyses of the size variable comparisons concerning EL, EW, EPe, EA, and EL/EW of the fasciolid eggs. In all analyses, the results were considered statistically significant when $p<0.05$.

\section{Results}

\subsection{Egg Embryonation}

The embryonation of F. hepatica eggs collected from fecal samples from llama was followed at $20^{\circ} \mathrm{C}$ up to the final miracidium development (Figure 3). The study showed that eggs including an outlined miracidium (E.O.M.) appeared from day 12, whereas eggs containing a completely conformed miracidium (E.D.M.) began to be detected from day 16. These E.D.M. eggs were subsequently found in each microscopic observation between days 16 and 24. E.D.M. egg percentages proved to follow a curve increasing up to a peak surpassing the $40 \%$ on day 24 , after which it rapidly decreased to 0 on day 28 , indicating that eggs including an outlined miracidium after this day were unable to subsequently give rise to a fully developed miracidium. The progressive increase in the percentage of broken eggs from day 12 up to day 40 is worth noting, similarly as the relatively high percentage of almost $30 \%$ of eggs still showing an inner morula on day 40 . The average egg embryonation (E.O.M., E.D.M.) along the 40 days showed lower values in the llama fecal isolate $(20.14 \%)$ when compared to the sheep isolate $(45.16 \%)$ and cattle isolate $(29.78 \%)$ from the Altiplano $(p<0.05)$.

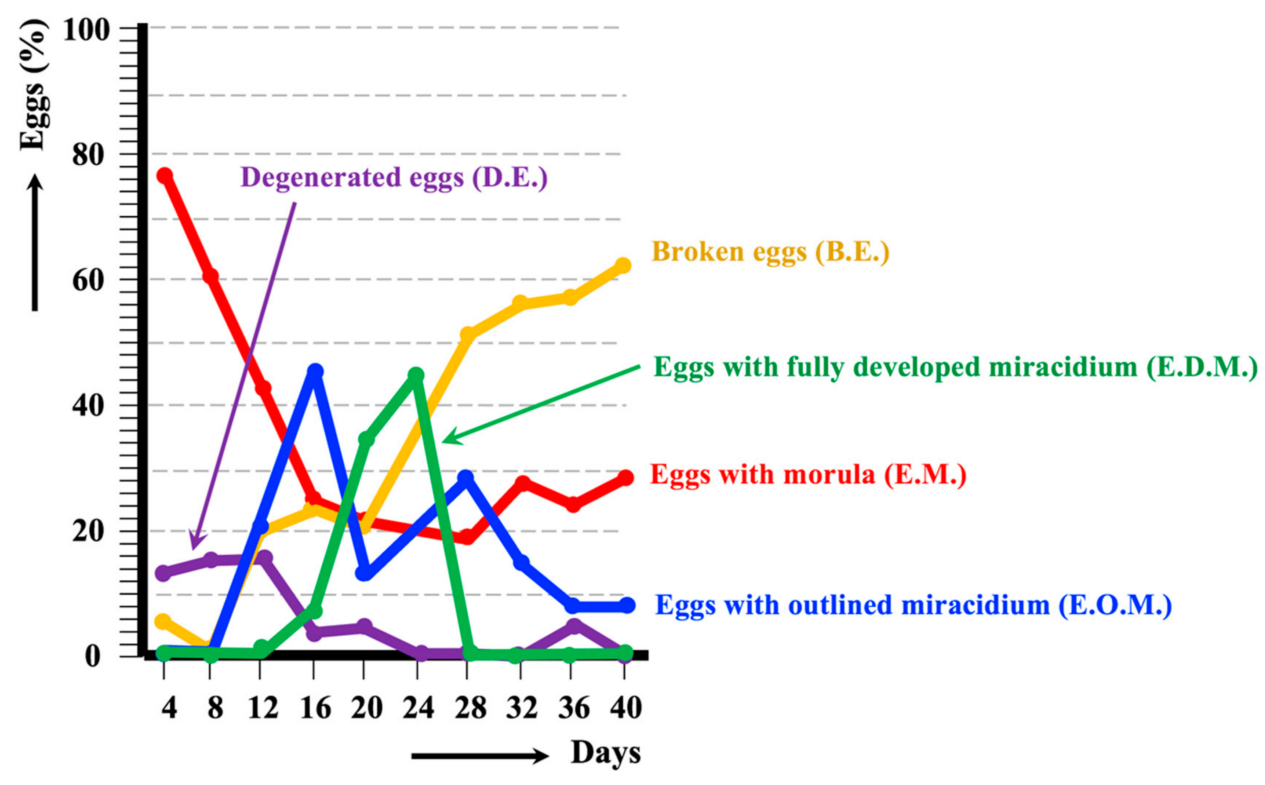

Figure 3. Graph showing the results of the experimental follow-up study of the egg embryonation of the isolate of Fasciola hepatica obtained from llama feces, and analyzed at 4-day intervals and constant temperature of $20^{\circ} \mathrm{C}$. 
In eggs collected from bile, embryonation could also be experimentally followed at $20^{\circ} \mathrm{C}$ up to the total conformation of the miracidium (Figure 4). The observational analyses showed that E.O.M. eggs appeared from day 16, but the first E.D.M. eggs only appeared from day 44 onwards. Eggs containing a fully developed miracidium were continuously observed daily until day 72 , although always in percentages lower than $10 \%$. The relatively high percentages of broken eggs and degenerated eggs, as well as eggs still presenting a morula at day 72 , should be highlighted. The average egg embryonation (E.O.M., E.D.M.) along the 72 days showed lower values in the llama bile isolate $(18.36 \%)$ when compared to the sheep isolate $(38.46 \%)$ and cattle isolate $(26.63 \%)$ from the Altiplano $(p<0.05)$.

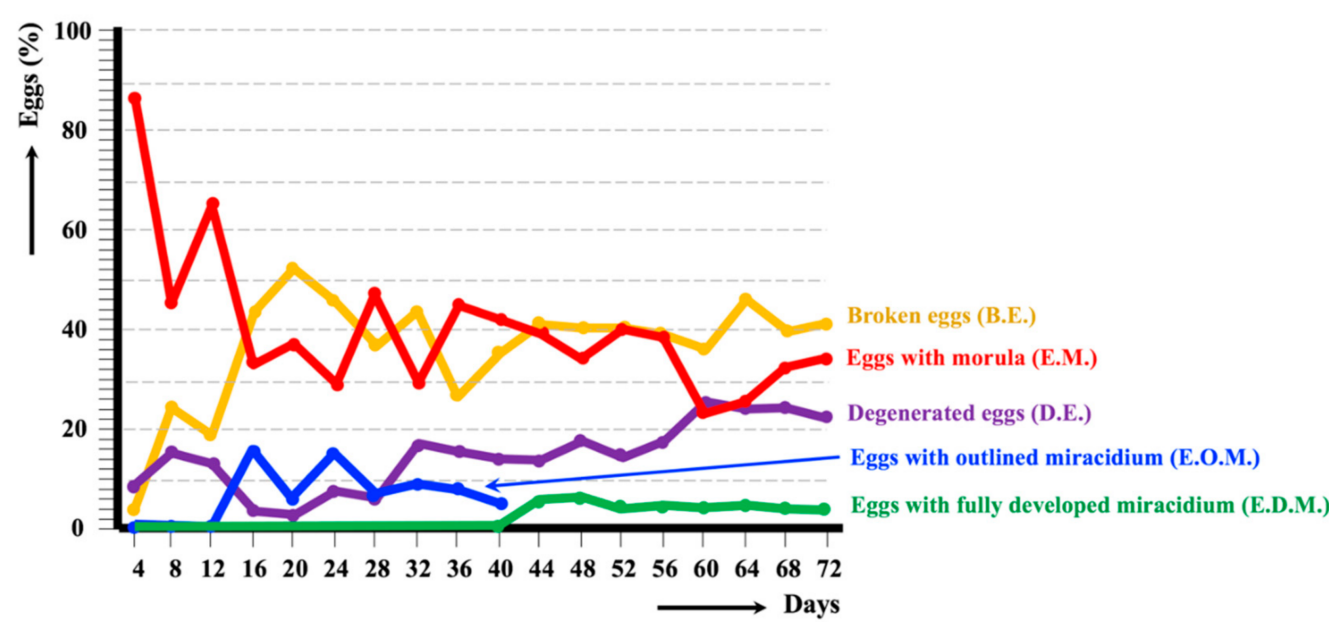

Figure 4. Graph showing the results of the experimental follow-up study of the egg embryonation of the isolate of Fasciola hepatica obtained from llama bile aspirate, and analyzed at 4-day intervals and constant temperature of $20^{\circ} \mathrm{C}$.

\subsection{Snail Infectivity and Intramolluscan Development}

The results of the snail vector infection assays performed with the Argentine llama isolate, including their comparison with the altiplanic $F$. hepatica isolates from sheep and cattle, are shown in Table 1. The llama isolate (33.3\%) was demonstrated to be somewhat more efficient than the isolate from cattle $(25.0 \%)$. Both llama and cattle isolates proved to be pronouncedly less efficient than the isolate from sheep (51.8\%). However, no statistically significant differences in the percentage of lymnaeids successfully infected by a monomiracidial dose at $20^{\circ} \mathrm{C} / 20^{\circ} \mathrm{C}$ (=the snail vector infectivity) between the llama isolate and the isolates of two ruminant reservoirs in the Bolivian Altiplano $(p>0.05)$ were detected.

The prepatent period of the llama isolate (39.4 days) showed an evidently lower mean value than the isolates from altiplanic sheep (55.6 days) and cattle (55.5 days). These differences in the prepatent period between the llama isolate and the isolates from the two main reservoirs proved to be statistically significant $(p<0.05)$. The period of cercarial emergence in the isolate of llama showed a mean value which proved to be pronouncedly shorter (mean: 12.2 days) than in those in the isolates from sheep (mean: 34.7 days) and cattle (mean: 47.1 days). From the statistical point of view, the duration of this emergence of cercariae in the llama isolate was significantly different from the length of this period in the isolates from sheep and cattle $(p<0.05)$.

The comparison of the production of cercariae between these $F$. hepatica isolates also furnished significant differences. The statistical analyses demonstrated that the cercarial production considered for each infected lymnaeid in the isolate from llama (mean: 51.3 cercariae/lymnaeid) was significantly different from those in the isolate from sheep (mean: 197.9 cercariae/lymnaeid) and cattle (mean: 306 cercariae/lymnaeid) $(p<0.05)$. 
Table 1. Experimental infections of Galba truncatula lymnaeid snails from Ancocagua, Northern Bolivian Altiplano human hyperendemic area, with Fasciola hepatica llama isolate from Quichagua, Argentina, and their comparison with results obtained in the F. hepatica sheep and cattle isolates from the Northern Bolivian Altiplano.

\begin{tabular}{cccc}
\hline Host Isolate & Llama & Sheep * & Cattle * \\
\hline F. hepatica geographical origin & Quichagua, Argentina & Batallas, Bolivia & Batallas, Bolivia \\
Lymnaeid geographical origin & Ancocagua, Bolivia & Huacullani, Bolivia & Huacullani, Bolivia \\
\hline Miracidial dose & mono-miracidial & mono-miracidial & mono-miracidial \\
Temperature (12h day/12h night) & $20{ }^{\circ} \mathrm{C} / 20^{\circ} \mathrm{C}$ & $20^{\circ} \mathrm{C} / 20^{\circ} \mathrm{C}$ & $20^{\circ} \mathrm{C} / 20^{\circ} \mathrm{C}$ \\
\hline No. lymnaeids infected & 45 & 62 & 55 \\
No. shedding snails (\%) & $30(66.7 \%)$ & $54(87.1 \%)$ & $48(87.3 \%)$ \\
Prepatent period in dpi (mean) & $10(33.3 \%)$ & $28(51.8 \%)$ & $12(25.0 \%)$ \\
Shedding end in dpi (mean) & $37-50(39.4)$ & $48-92(55.6)$ & $49-76(55.5)$ \\
Shedding length in days (mean) & $37-74(50.6)$ & $52-136(89.4)$ & $58-135(101.6)$ \\
No. total cercariae shed & $1-38(12.2)$ & $1-88(34.7)$ & $1-85(47.1)$ \\
No. cercariae/snail (mean) & 513 & 5542 & 3672 \\
Snail survival after shedding end in days (mean) & $1-180(51.3)$ & $8-562(197.9)$ & $8-581(306.0)$ \\
Longevity of shedding snails in dpi (mean) & $1-31(7.3)$ & $1-132(24.5)$ & $1-133(42.3)$ \\
Longevity of non-shedding snails in dpi (mean) & $30-76(57.9)$ & $53-192(113.8)$ & $76-268(143.9)$ \\
\hline
\end{tabular}

dpi = days post-infection. * Data from Mas-Coma et al. [24].

Interesting results were obtained in the analysis of the influence of the infection on the lymnaeid vectors, including the aspects of the survival of the lymnaeids after the end of shedding days, the longevity of the infected shedding lymnaeids, and also the survival length of the non-shedding lymnaeids. In the isolate from llama, all of the aforementioned aspects were demonstrated to be statistically different from those in the isolates from sheep and cattle $(p<0.05)$. These differences were clearly obvious by both the mean and maximum dpi values, which were markedly shorter in the llama isolate when compared to the isolates from altiplanic sheep and cattle (Table 1).

\subsection{Chronobiological Pattern of The Cercarial Emergence}

The chronobiology of the cercarial shedding observed in the llama isolate is shown in Figure 5. The shedding period was analyzed according to two points of view (Figure 5A-D).

On one side, the study concerned the average amounts of cercariae which were shed daily (Figure 5A) and weekly (Figure 5B) by all shedding lymnaeids involved in a follow-up from the day of the emergence of the first cercaria by each snail. The complete length of this period lasted up to 38 days or 6 weeks, with an average of 12.2 days (Table 1). The daily process of cercarial emergence showed several waves according to an irregular succession including several peaks. Among them, the highest peak does not appear until day 17, i.e., pronouncedly delayed regarding the first cercarial shedding day. The curve computing weekly emergences showed that it was throughout the third week when cercariae shed presented their highest numbers. Interestingly, there is a period of lack of daily shedding between days 21 and 28, after which shedding restarts and is irregularly maintained until final exhaustion.

Conversely, the emergence was studied from the day of the miracidial infection of each snail. In this second analysis, the period of the emergence of cercariae showed daily and weekly curves (Figure 5C,D) which are very similar to those of the chronobiology when analyzed from the day of the first cercarial shedding by each lymnaeid (Figure 5A,B). This is due to the fact that $70 \%$ of the snails, including the big shedders (up to 92 cercariae/snail), started shedding on the same day, i.e., identical prepatent period, whereas the remaining $30 \%$ delayed snails were only specimens that shed a small number of cercariae (8-23 cercariae/snail; mean 14.3 cercariae/snail). 

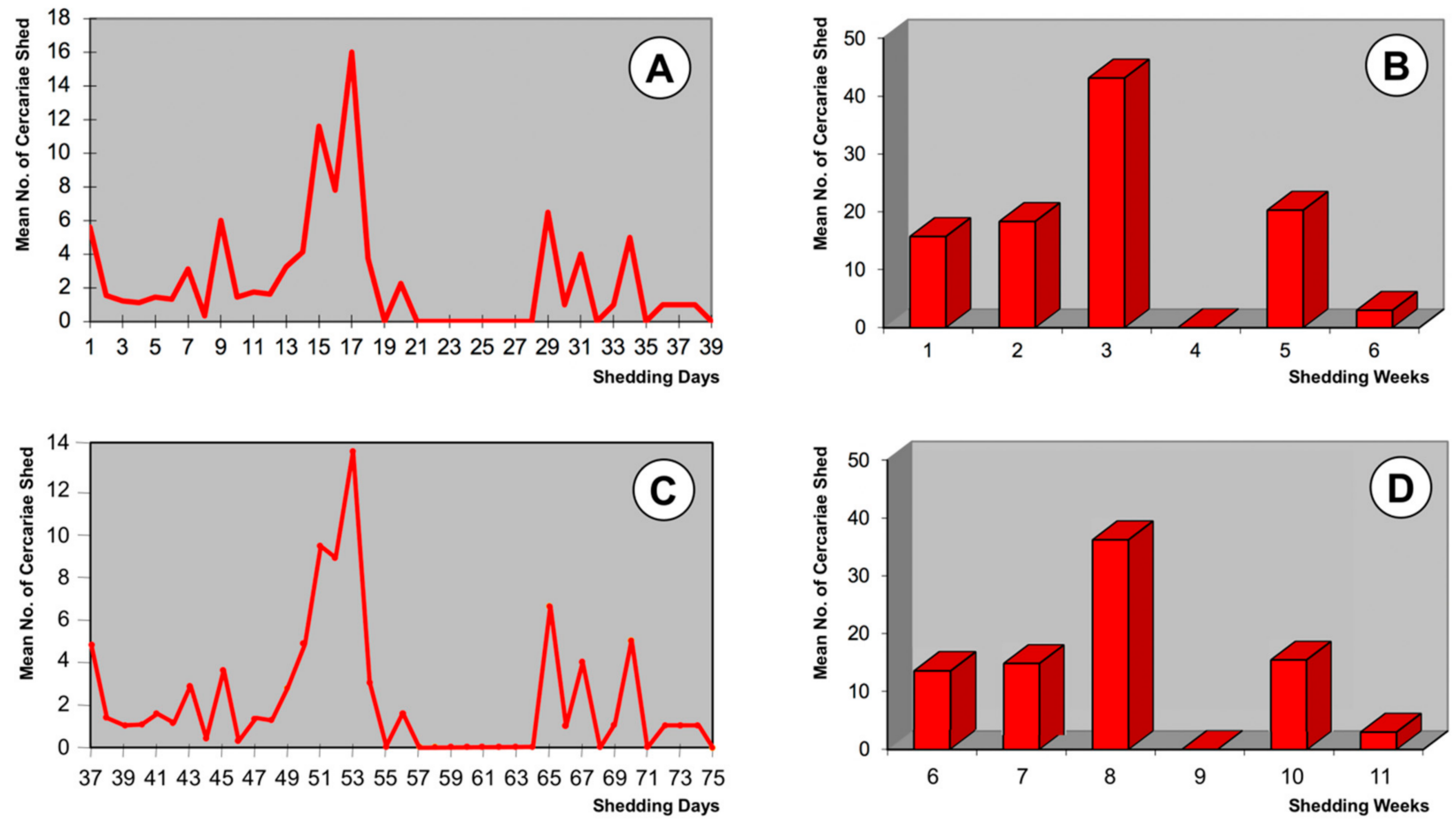

Figure 5. Chronobiological patterns of cercarial emergence by Galba truncatula from the Northern Bolivian Altiplano monomiracidially infected with the llama isolate of Fasciola hepatica from the Argentine high Andean plateau: (A,B) shedding period analyzed according to the mean amounts of cercariae shed daily and weekly from the day of the emergence of the first cercaria by each snail; (C,D) shedding period analyzed according to the mean amounts of cercariae shed daily and weekly from the day of the miracidial infection; prepatent period not shown.

\subsection{Experimental Infectivity of Mammal Host}

Assays performed in the laboratory to assess the infection capacity of metacercariae of the Argentine F. hepatica isolate from llama and carried out with Wistar rats are shown in Table 2. The comparison of infectivity results concerning the percentages of successfully infected animals (52.0\% in the llama isolate versus $78.4 \%$; and $75.0 \%$ in the sheep and cattle isolates, respectively) demonstrated that, despite the evidently lower value in the llama isolate, there were no statistically significant differences $(p>0.05)$. Additionally, the infection burden or intensity, expressed by fluke number per inoculated metacercariae and per animal, neither showed significant differences in the comparison of the isolate from llama with that from sheep $(p>0.05)$.

Table 2. Experimental infections of Wistar rats with experimentally obtained metacercariae from the llama isolate from Quichagua, Argentina, and comparison with sheep and cattle isolates from the Northern Bolivian Altiplano human hyperendemic area.

\begin{tabular}{|c|c|c|c|c|c|}
\hline \multirow{2}{*}{$\begin{array}{c}\text { Host Isolate } \\
\text { F. hepatica geographical origin }\end{array}$} & \multirow{2}{*}{$\begin{array}{l}\text { Llama } \\
\text { Quichagua, } \\
\text { Argentina }\end{array}$} & \multicolumn{2}{|c|}{ Sheep *** } & \multicolumn{2}{|c|}{ Cattle *** } \\
\hline & & $\begin{array}{l}\text { Batallas, } \\
\text { Bolivia }\end{array}$ & $\begin{array}{c}\text { Ancocagua, } \\
\text { Bolivia }\end{array}$ & $\begin{array}{l}\text { Kallutaca, } \\
\text { Bolivia }\end{array}$ & $\begin{array}{c}\text { Batallas, } \\
\text { Bolivia }\end{array}$ \\
\hline Age of metacercariae & 8-11 weeks & 1 week & 2 weeks & 6 weeks & 8 weeks \\
\hline No. metacercariae inoculated per rat & 20 & 20 & 20 & 20 & 20 \\
\hline No. inoculated rats & 25 & 14 & 23 & 4 & 4 \\
\hline No. rats infected $(\%)$ & $13(52.0 \%)$ & $11(78.6 \%)$ & $18(78.3 \%)$ & $4(100 \%)$ & $2(50.0 \%)$ \\
\hline No. flukes recovered per rat (mean) & $1-10(5.2)$ & $1-8(3.6)$ & $1-10(3.7)$ & $1-2(1.7)$ & $1-2(1.5)$ \\
\hline Intensity * & $13.6 \%$ & $14.3 \%$ & $14.6 \%$ & $8.8 \%$ & $3.7 \%$ \\
\hline Mean $\%$ flukes recovered $/$ rat $^{* *}$ & $26.1 \%$ & $18.2 \%$ & $18.6 \%$ & $8.8 \%$ & $7.5 \%$ \\
\hline
\end{tabular}

${ }^{*}$ Intensity $=$ total $\%$ of flukes recovered $=$ (total No. of flukes recovered $/$ total No. of metacercariae administered in all rats) $\times 100 .{ }^{* *}$ Mean

$\%$ flukes recovered $/ \mathrm{rat}=$ Mean $\%$ of flukes recovered per infected rat $=($ flukes recovered $/$ metacercariae administered per infected rat $) \times$

100. ${ }^{* * *}$ Data from Mas-Coma et al. [24]. 


\subsection{Prevalence, Intensity, Egg Measurements and Shedding Rates}

A prevalence of $21.6 \%$ was found in a study of fecal samples from 88 llamas of 39 herds in the Argentine high Andean plateau of Quichagua area, but a pronouncedly lower prevalence of $4.2 \%$ was later observed in fecal samples from 708 llamas of 89 herds coming from the Argentine provinces of Salta, Jujuy, and Catamarca.

In Quichagua, infection intensity could be assessed in 14 female llamas and 1 male llama aged 2 years by fasciolid egg counting in their fecal samples. The quantitative coprological analyses showed an intensity ranging between 1 and $10 \mathrm{epg}$. Additionally, a total of 62 adult flukes could be recovered from the liver of an occasionally slaughtered female llama, which presented with macroscopic hepatic lesions suggesting chronic infection despite no visible symptom attributable to liver fluke infection.

In the Northern Bolivian Altiplano, fecal samples from llamas could only be obtained at a weekly trade fair of llamas in the locality of Palcoco (Figure 6E,F) in the month of March, which is usually the last month of the rainy season. A total of 30 llamas present in the Palcoco trade fair were surveyed. None showed liver fluke eggs in their feces.

A total of 36 and 37 eggs from fecal and bile samples of llama, respectively, were measured (Figure 7A-C). Table 3 includes the measurements obtained in the morphometric study of the F. hepatica eggs of the llama isolate and their comparison with the same measurements of eggs from sheep and cattle of the Bolivian Altiplano. The corresponding analyses by means of post hoc statistical tests, such as L.S.D., Student-Newman-Keuls, and Duncan's tests, showed that the liver fluke eggs in llamas are significantly smaller than the eggs in the ruminant isolates, except the length/width ratio $(p<0.05)$.

Table 3. Comparison of egg measurements (A) and egg shedding (B) between the Fasciola hepatica llama isolate from Argentina and the sheep and cattle isolates from the Northern Bolivian Altiplano human hyperendemic area.

\begin{tabular}{|c|c|c|c|c|c|c|c|c|}
\hline \multicolumn{3}{|c|}{ Host } & \multicolumn{2}{|c|}{ Llama } & \multicolumn{2}{|c|}{ Sheep } & \multicolumn{2}{|c|}{ Cattle } \\
\hline \multicolumn{9}{|c|}{ (A) Egg Measurements } \\
\hline Eggs & \multicolumn{2}{|c|}{ Fecal Samples $(n=36)$} & \multicolumn{2}{|c|}{ Bile Samples $(n=37)$} & \multicolumn{2}{|c|}{ Fecal Samples $(n=104)$} & \multicolumn{2}{|c|}{ Fecal Samples $(n=168)$} \\
\hline $\begin{array}{l}\text { Measure-ments } \\
\qquad(\mu \mathrm{m})\end{array}$ & Range & Mean \pm SD & Range & Mean \pm SD & Range & Mean \pm SD & Range & Mean \pm SD \\
\hline EL & $103.8-139.9$ & $124.2 \pm 9.1$ & $105.7-146.7$ & $120.9 \pm 9.2$ & $114.8-151.2$ & $130.8 \pm 7.1$ & $105.3-155.9$ & $132.0 \pm 10.5$ \\
\hline EW & $57.6-74.5$ & $66.6 \pm 3.5$ & $54.9-76.3$ & $65.5 \pm 5.4$ & $65.5-81.4$ & $72.6 \pm 3.9$ & $61.7-82.5$ & $71.1 \pm 4.4$ \\
\hline $\mathrm{EPe}$ & $284.3-350.6$ & $321.8 \pm 17.6$ & $277.4-363.2$ & $314.7 \pm 19.5$ & $294.2-368.2$ & $327.6 \pm 15.0$ & $270.6-422.9$ & $340.0 \pm 33.4$ \\
\hline EA & $\begin{array}{c}5022.4- \\
7269.5\end{array}$ & $\begin{array}{c}6399.9 \pm \\
625.1\end{array}$ & $4761.5-7570.7$ & $6108.8 \pm 728.2$ & 5998.2-8608.4 & $7238.0 \pm 532.8$ & $5286.5-9676.8$ & $7170.2 \pm 802.5$ \\
\hline EL/EW & $1.52-2.13$ & $1.8 \pm 0.15$ & $1.5-2.3$ & $1.8 \pm 0.2$ & $1.5-2.1$ & $1.8 \pm 0.1$ & $1.6-2.3$ & $1.8 \pm 0.2$ \\
\hline \multicolumn{9}{|c|}{ (B) Egg Shedding } \\
\hline \multicolumn{3}{|c|}{ Intensity (epg) } & \multicolumn{2}{|c|}{$1-10$} & \multicolumn{2}{|c|}{ 3-241 (a) } & \multicolumn{2}{|c|}{ 1-96 (a) } \\
\hline \multicolumn{3}{|c|}{ Stools/day (kg) } & \multicolumn{2}{|c|}{$0.7-3.9(\mathrm{c})$} & \multicolumn{2}{|c|}{$1-3(b)$} & \multirow{2}{*}{\multicolumn{2}{|c|}{$\begin{array}{c}15-35(b) \\
15,000-3360,000\end{array}$}} \\
\hline \multicolumn{3}{|c|}{ No.eggs/animal/day (d) } & \multicolumn{2}{|c|}{$700-39,000$} & \multicolumn{2}{|c|}{$3000-723,000$} & & \\
\hline
\end{tabular}

EL: egg length; EW: egg width; EPe: egg perimeter; EA: egg area; EL/EW: egg length/egg width. Measurement values shown as range and mean \pm standard deviation (S.D.). (a) = according to Mas-Coma et al. [24]; (b) = according to various sources; (c) = after Anderson [76] and Adam and Adam [77]; (d) = estimations of the range of the number of F. hepatica eggs fecally shed by an animal per day in the Bolivian Altiplano.

When considering the infection intensity in llamas varying between 1 and 10 epg and the number of stools defecated by a llama individual per day, the total number of F. hepatica eggs fecally shed by a camelid individual per day could be calculated (Table 3$)$. The daily egg output per llama per day proved to be pronouncedly lower than the same estimations made for both sheep and cattle. 

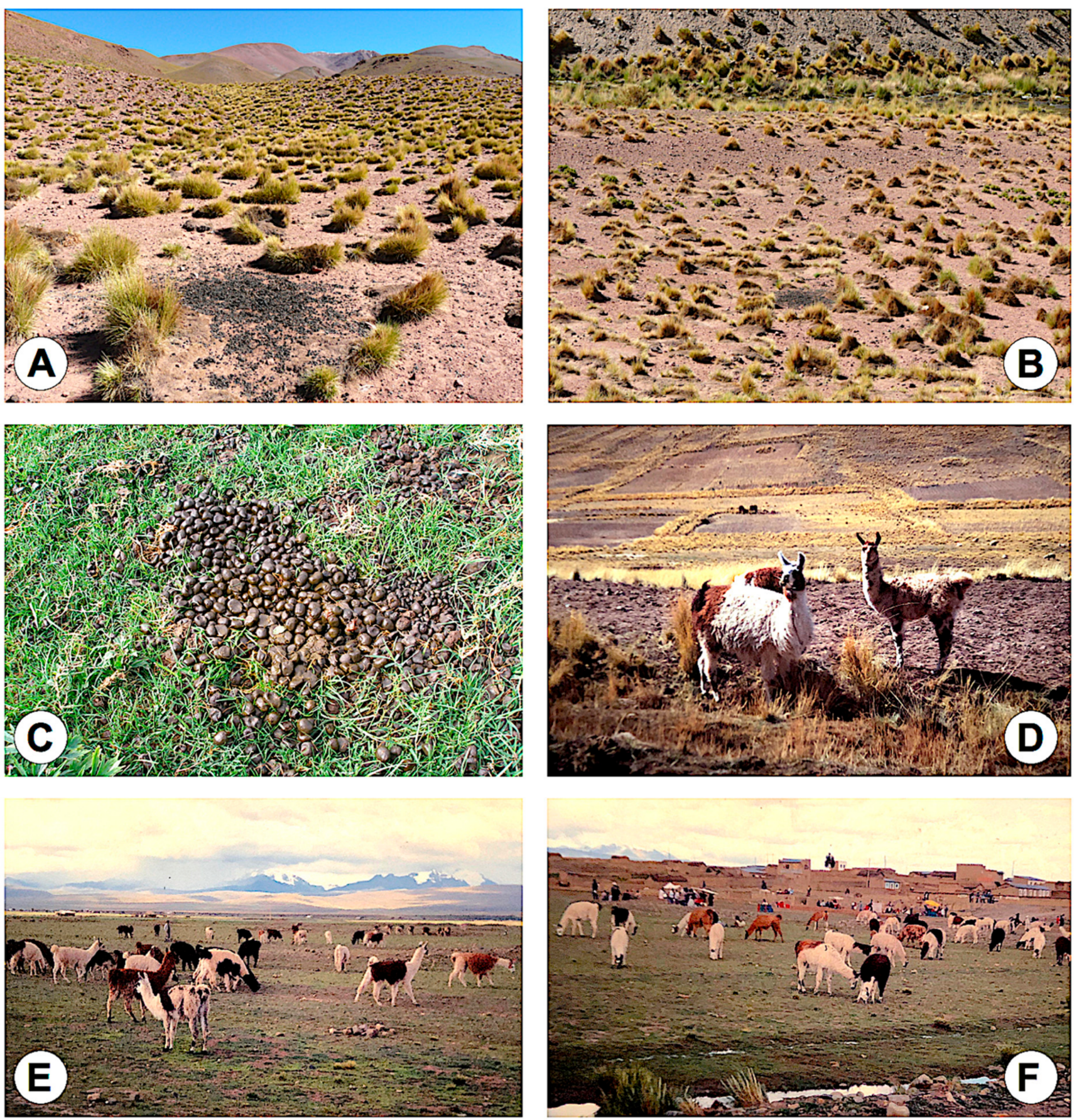

Figure 6. Llamas in the Argentine high Andean plateau and the Northern Bolivian Altiplano: (A) Typical dung pile in an Argentine Andean highland prairie; (B) Another dung pile located far away from small stream that rises from the slope sources in an Argentine Andean highland prairie (see background); (C) Dung pile showing fecal particles of llama commonly called "llama beans"; (D) Llamas in the northeastern part of the "corridor of Peñas" (see slope of the mountainous foothills of the Eastern Andean chain in the background and note surrounding aridity and absence of freshwater collections); $(\mathbf{E}, \mathbf{F})$ weekly trade fair of llamas in the locality of Palcoco in the Northern Bolivian Altiplano (note the absence of big "llamas cargueras"). (A,B): Photographs by A.J. Mangold; (C): Photograph by M.M. Cafrune; (D-F): Photographs by S. Mas-Coma. 

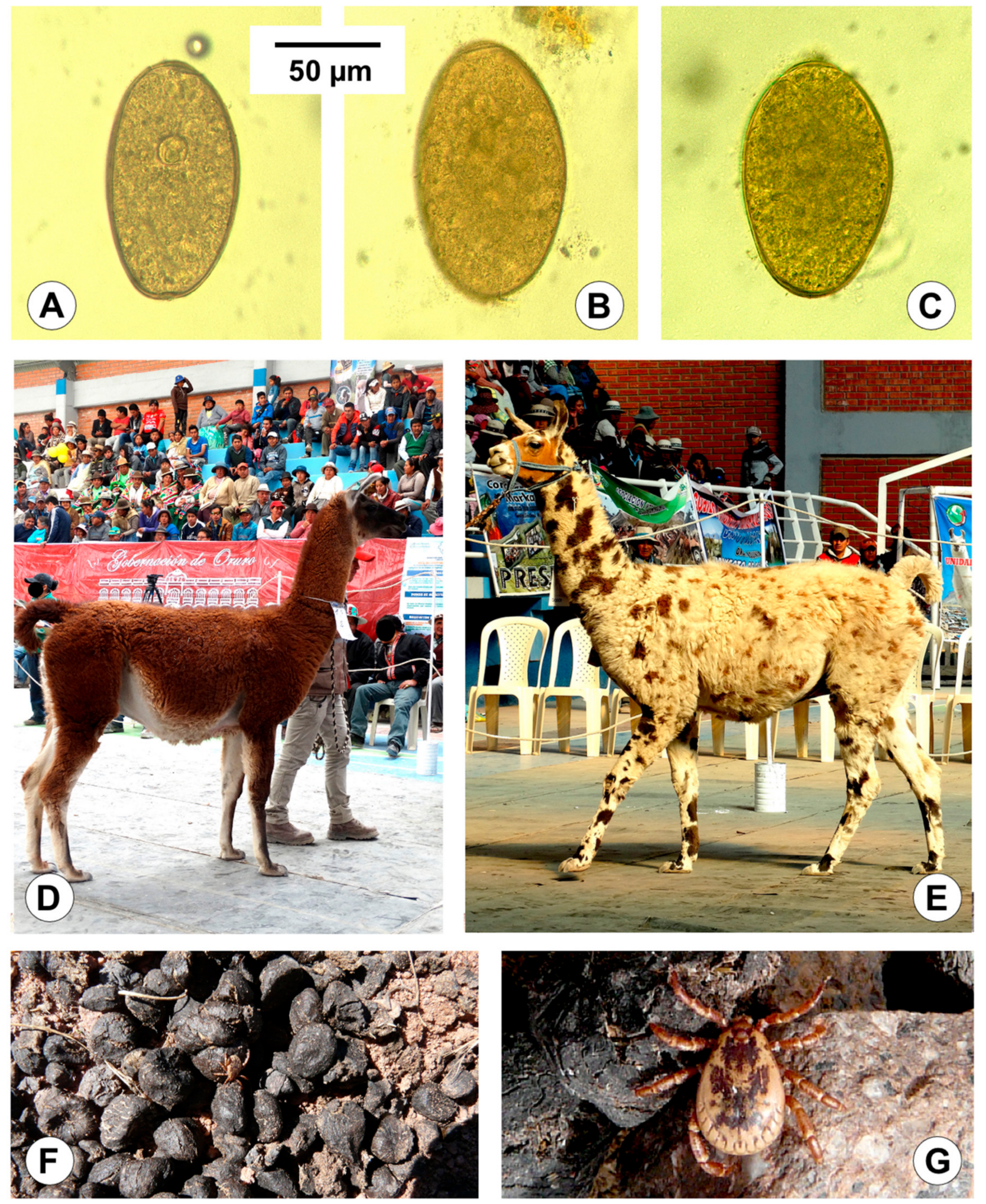

Figure 7. Fascioliasis and llamas in the high Andean plateaus of Argentina and Bolivia: (A-C) Eggs of Fasciola hepatica in fecal samples of llamas from Quichagua, Argentina (photographs at the same scale); (D,E) llamas for good transport ("llamas cargueras", "Karas" or "Peladas") in the yearly national camelid trade fair in the locality of Turco, Oruro, in the Central Bolivian Altiplano (note their big size when comparing with the height of the person behind); (F,G) Tick specimens of Amblyomma parvitarsum waiting in between "llama beans" (this specific tick behavior indicates a very long evolutionary adaptation to a particular defecating behavior of its llama host). (A-C): Photographs by M.M. Cafrune; (D,E): Photographs by Ing. Hugo Eduardo Lamas (Abra Pampa, Jujuy, Argentina); (F,G) Photographs by A.J. Mangold. 


\section{Discussion}

\subsection{Egg Embryonation}

\subsubsection{Egg Embryonation in the Llama Isolate}

In the life cycle of liver flukes belonging to the genus Fasciola, eggs fecally shed by several species or geographical strains of local hosts are known to be unable to reach the total embryonation of the miracidium. The development of the miracidium inside the egg is thus a crucial characteristic to look for when assessing the viability of a mammal species isolate. Indeed, egg formation, production, development, and viability are aspects analyzed within the egg hatch assays used for drug efficiency evaluation [78].

Egg embryonation is a temperature-dependent process. The time needed to reach a fully developed miracidium inside the egg is longer at lower temperatures. A temperature of $20{ }^{\circ} \mathrm{C}$ has been used for the egg embryonation of the llama isolate to allow for the appropriate evaluation by comparison with the sheep and cattle isolates also from very high altitude and analyzed at the same constant temperature according to exactly the same methodology to obtain significant results.

In ruminant isolates, the hatching time at $20^{\circ} \mathrm{C}$ has been observed to vary between 19-20 days [79] and 27 days [80]. In the isolates of sheep and cattle isolates from the Northern Altiplano of Bolivia, the first completely conformed miracidium appeared at day 24 , and eggs presenting this final miracidium stage were uninterruptedly found until the end of the observational study of 143 days [24]. In the llama isolate, the stage of fully developed miracidium was reached in both follow-up studies of eggs collected from fecal samples and from bile. However, embryonation results in both feces and bile indicate an egg development pronouncedly less successful than in the sheep and cattle isolates. The high percentage of eggs including a morula throughout the whole follow-up shows that many eggs are not able to continue their development. Moreover, the high percentage of broken eggs, whether gradually increasing in feces (Figure 3) or maintained at high values in bile, together with the increasing proportion of degenerated eggs also in bile (Figure 4), indicate a lack of viability in many eggs.

\subsubsection{Miracidial Infectivity, Intramolluscan Development and Cercarial Chronobiology}

There is a large complexity and variability in the processes of snail infectivity and fasciolid larval stage development linked to the many different factors involved, as has been observed in studies about the interactions between F. hepatica and G. truncatula [81].

The snail infectivity of the llama isolate with a mono-miracidial dose at a constant temperature of $20{ }^{\circ} \mathrm{C}$ was $33.3 \%$ (Table 1). This is in agreement with the $14.0-56.8 \%$ range experimentally found in different populations of the same lymnaeid vector species G. truncatula in France [82,83], similarly as regarding the $25.0-51.8 \%$ observed in altiplanic isolates from sheep and cattle [24].

The prepatent period (from infection up to the shedding of the first cercaria) in the llama isolate proved to be shorter than that found in altiplanic sheep and cattle isolates [24] (Table 1), which in their turn proved to be slightly longer than in F. hepatica/G. truncatula of the lowlands $[79,84,85]$. This shorter prepatent period of the llama isolate remembers the similar precociousness observed in the embryogenesis of viable eggs from llama.

The mean length of the patent period (length of the cercarial shedding period) in the llama isolate also proved to be pronouncedly shorter than the same period in the sheep and cattle isolates from the Bolivian Altiplano [24] (Table 1) and also from that in F. hepatica from ruminants of the lowlands $[82,86]$.

The cercarial shedding chronobiology in the llama isolate shows similar daily and weekly patterns in both the curve from the day of the emergence of the first cercaria by each snail (Figure 5A,B) and in the curve from the day of the miracidial infection (Figure 5C,D), because most infected snails began simultaneously with shedding. In all these curves, two shedding phases separated by a non-shedding period in week four are observed. Instead of an initial shedding peak and subsequent gradual progressive decrease as observed in the altiplanic sheep and cattle isolates [87], in the llama isolate there was only a delayed 
acrophase. The pattern of shedding of cercariae found in the llama isolate does neither fit the pattern of 1-14-waves, including the pattern of 4-5-waves followed by the majority, observed in F. hepatica infecting G. truncatula of the lowlands analyzed under constant temperature and photoperiod conditions [88]. The pauses in the curve analyzed from the day of the miracidial infection have been linked to the redial generation replication processes [87]. In the case of the llama isolate, results may be interpreted as including only two cercariogenous redial generations, one before and the other after the aforementioned multiday pause.

\subsubsection{Cercarial Production, Lymnaeid Survival and Metacercarial Infectivity}

Worth mentioning is the cercarial production capacity of the llama isolate, which was 51.3 cercariae/snail, a markedly lower quantity when compared to the 197.9 cercariae/snail and 306.0 cercariae/snail of the sheep and cattle isolates from the Bolivian Altiplano, respectively [24] (Table 1). This llama isolate production is even lower than the low productions found in F. hepatica infecting G. truncatula in several populations of lowland areas, such as 91.7 cercariae/snail [89] or 120.0 cercariae/snail [90].

Snail survival after shedding end, the longevity of shedding snails, and the longevity of non-shedding snails in infections by the llama isolate are also shorter than in those obtained when infecting with the altiplanic sheep and cattle isolates (Table 1) [24]. Interestingly, this longevity has been proven to be longer in infected snails inhabiting areas of high altitude than the duration of the same period in F. hepatica infecting G. truncatula in the lowlands, a phenomenon which has been observed to be independent on the host isolate of F. hepatica [91].

The results of the experimental infections of Wistar rats showed the definitive host infectivity of metacercariae of the llama isolate (Table 2). The experimental prevalence obtained fitted well in the results obtained with the altiplanic sheep and cattle isolates, and the intensity with that of the sheep isolate [24], and also in the present knowledge when dealing with short-aged metacercariae of ruminant origin [63,92].

\subsection{Epidemiological Role of the Llama}

A prevalence of $21.6 \%$ was found in the animal endemic Argentina high Andean plateau at Quichagua and a prevalence of $4.2 \%$ in subsequent wider surveys in neighboring zones in Argentina. However, none of the 30 llamas analyzed in the Northern Bolivian Altiplano at Palcoco showed infection. Indeed, local prevalence of liver fluke infection in llamas varies pronouncedly according to localities: between $8 \%$ and $35 \%$ in Peru [55,93], $16.4 \%$ in the USA [94], 49.5\% also in Peru [56], and up to 80\% in Argentina [34,95,96].

In the Northern Bolivian Altiplano human hyperendemic area, llamas can only very sporadically be observed. Besides the few specimens present in the garden of the Titicaca Hotel and the Tiwanaku ruins, both for mere touristic purposes, only a few individuals can regularly be found in the north-eastern part of the altiplanic corridor of Peñas (Figure 6D) and in the altiplanic corridor of Huancarani-Jesús de Machaca. However, the latter two places lie outside of the wide human endemic area. Additionally, llamas concentrate once a week in a trade fair specialized on this Andean camelid in the locality of Palcoco. The llamas of this weekly fair mainly come from zones outside of the endemic region, such as from:

- the zone located north of the endemic area, at a higher altitude on the way to the Eastern Andean Chain; it should be considered that there is no fascioliasis transmission in places located at an altitude higher than $4000 \mathrm{~m}$ a.s.l. due to the inability of the transmitting lymnaeids to survive at the temperature of such extreme altitudes [28];

- the altiplanic zone located south of the endemic area, on the way to Oruro, where temperatures are colder owing to the absence of the milder climatic influence of Lake Titicaca [97], which similarly explain the absence of lymnaeid vectors [28]; indeed, none among a total of 404 llamas from the Oruro department $(82.4 \%$ from Sajama province, $8.7 \%$ from San Pedro de Totora province, $5.4 \%$ from Carangas province, and 
$3.5 \%$ from Litoral province) analyzed in the slaughterhouse of the locality of Turco, close to the city of Oruro, were found to be infected [98].

Liver fluke infection has been reported from alpacas in the Northern Bolivian Altiplano. However, it should be highlighted that, in the Northern Bolivian Altiplano, besides a very few isolated individuals together with llamas regularly found in the northeastern part of the "corridor of Peñas" (Figure 6D), alpacas are only found on the farm of Belén, northward of Achacachi, both outside of the human fascioliasis transmission area. Previous coprological studies on alpacas from Belén farm [44,45] reported the following results: in one study $59.1 \%$ of 22 alpacas were detected shedding F. hepatica eggs, with averages of 75,16 , and 2 eggs found in animals with high $(n=7)$, moderate $(n=2)$ and low $(n=2)$ infection, respectively; in another survey, 25 alpacas among 29 studied showed eggs in their feces (86.2\%), of which 22 alpacas presented fewer than 10 epg, 2 alpacas showed between 10 and $30 \mathrm{epg}$, and only 1 alpaca presented more than $30 \mathrm{epg}$. According to these data, alpacas may be taken into account in the zone of the Belén farm but can be discarded regarding a potential reservoir role in the human endemic area.

The intensity of 1-10 epg found in llamas from Quichagua is very low when compared with the intensities found in altiplanic sheep and cattle (Table 3). In llama, egg output ranges reaching pronouncedly higher maximums have been reported, such as $0.6-253.2 \mathrm{epg}$ in domesticated specimens in the USA [99] and 1-332 epg (mean 42 epg) in a farm in the UK [100], although lower ones of $12.6 \pm 1.9 \mathrm{epg}$ (geometric mean \pm standard deviation) were found in endemic areas of Peru [56]. The 62 liver flukes recovered from the slaughtered llama in Quichagua is a number lower than the 154 flukes found in experimentally infected llamas [99].

Fasciola hepatica eggs shed by naturally infected llamas from Quichagua showed size and form characteristics similar to those previously found in this camelid species: $123.2 / 68.6 \mu \mathrm{m}$ in the USA [99]; 102.1-148.4/57.9-86.9 $\mu \mathrm{m}$ (mean $126.7 / 72.0 \mu \mathrm{m}$ ) with an EL/EW ratio of 1.76 in Peru [56]. The measurements of liver fluke eggs shed by llamas prove to be smaller than those shed by sheep and cattle isolates from the Northern Bolivian Altiplano (Table 3) [24,101].

The total number of liver fluke eggs daily expelled with feces by a llama in Quichagua, according to the number of stools defecated by a llama per day [76,77], may be estimated to be between 700 and 39,000 eggs/llama/day (Table 3). Only slightly higher rates around 49,140 eggs/llama/day are obtained when considering egg outputs by llamas in endemic areas of Peru [56]. Such ranges appear to be markedly lower than those calculated for the main reservoirs of sheep and cattle [24].

Llamas appear to be very susceptible to fascioliasis, with a histopathological picture similar to that shown by sheep [99]. The animal survival to infection should be taken into account in control initiatives, mainly in areas of high transmission rates leading to very high individual fluke intensities by infection and re-infection [102,103], such as in the Northern Altiplano human hyperendemic areas of Bolivia [24] and Peru [54], or in Andean valleys of Peru [13]. It should be considered that the contribution to the transmission of fascioliasis may only be for a short time in the case of a mammal that only survives a given period after the liver fluke infection. Such a contribution may therefore be negligible when compared with other definitive hosts which are able to transmit for longer periods or even the post-infection rest of their long life [25].

The more common hosts of $F$. hepatica may be divided into three groups based on an early, delayed, or low level of resistance [104]:

- Group I: It includes early resistance hosts characterized by possessing tissues that are not suitable for the fluke and resulting in a high degree of natural resistance. The infection is self-limiting without harming the host. The domestic pig is an example.

- Group II: This concerns the delayed resistance hosts characterized by a resistance that is acquired during the first weeks of a primary infection or during challenge infection. A delayed host reaction controls flukes during tissue migration, and chronic reactions 
including bile duct calcification lead to the eventual elimination of infection. Mortality is not common. Cattle and horses represent this group.

- Group III: Host species of this group have low resistance resulting in severe tissue reactions that do not immobilize or eliminate the parasites. In the chronic condition, there is no calcification of the bile ducts and flukes often survive the life of the host. Mortality in both the acute and chronic phases is common. Sheep and goats are hosts included in this group.

The bile ducts of South American camelids show more similarity with the equine bile system than with the bile system of domestic ruminants [105]. Despite this, the histopathological picture of fascioliasis in llamas suggests a low resistance to liver fluke infection and has been reported to be more similar to that in sheep $[99,100,106]$ than to that in equines [107]. Indeed, F. hepatica infection is a common cause of production loss and mortality in domesticated New World camelids $[44,55,57,58,108]$. Its impact in alpacas has led to many studies about diagnostics and treatment $[58,59,109]$.

Nevertheless, surveys in Andean endemic areas showed low intensities in llamas $[34,56,95,96]$, which are far from the high burdens which may be reached in confinement situations of domesticated animals $[99,100]$. Low burdens in llamas in the open field may be linked to their peculiar defecation behavior. These animals deposit their fecal excretions (fecal particles of llama are commonly called llama beans because of their aspect) in dung piles (Figure 6A-C). Although there may usually be several dung piles within any one field or pasture, it is evident that llamas are extremely hygienic as compared with sheep, goats, cattle, and equines. These dung piles reduce the spreading capacity of the fecal pathogens, opposite to the other livestock species which defecate everywhere and thus contribute to a wider spread of the parasites. Interestingly, a contrary evolutionary trend appears to be followed by the tick species Amblyomma parvitarsum (Acari: Ixodidae), which has adapted to this particular defecation behavior and waits in these dung piles to facilitate its access to the llamas (Figure 7F,G) [110]. Moreover, llamas always make these dung piles far away from freshwater collections (Figure 6B), which prevents lymnaeid snail infection by eggs shed by this camelid. Such lower F. hepatica intensity rates in llamas do not suggest fascioliasis to induce high pathogenicity pictures shortly leading to death in the open field.

\section{Concluding Remarks}

The results of the present experimental studies demonstrate that the llama is a definitive host species in which F. hepatica is able to close its complete life cycle. However, the follow-up of the llama isolate, by means of a highly efficient lymnaeid vector species in altitude areas such as G. truncatula, indicates that F. hepatica does not reach in this camelid species the level of adaptation this parasite shows in sheep and cattle in Andean altitude areas as in the Northern Bolivian Altiplano.

In the llama isolate, the egg embryonation showed a lack of viability in many eggs and an overall pronouncedly less successful development than in the sheep and cattle isolates. Moreover, results have shown shorter prepatent and patent periods leading to a markedly lower cercarial production capacity, a shorter cercarial shedding chronobiology with only one delayed acrophase, and a higher negative impact on snail survival.

Additionally, the usually low infection intensities of llamas and consequent low daily fecal outputs of liver fluke eggs in Andean endemic areas, together with the peculiar defecation behavior in dung piles of this camelid, should be taken into account.

All in all, the results demonstrate that the llama should not be considered an important definitive host when compared to sheep and cattle in Andean endemic areas [24]. The quantitatively lower contribution of the llama to the transmission of F. hepatica and the peculiar defecating behavior in dung piles always far from freshwater collections suggest that there are sufficient reasons as to consider the reservoir role of the llama as negligible and, therefore, no priority within control measures in endemic areas. In the Northern Bolivian 
Altiplano human hyperendemic area, neither llamas nor alpacas should be considered for control measures within a One Health action.

Complete studies similar to the present one should be performed on other local llama isolates to see whether the liver fluke may perhaps have better adapted to the llama in endemic areas of other Andean countries.

However, it should be considered that llamas may play a disease-spreading role if used as pack animals in rural areas (Figures 7D,E and 8), as already highlighted in the case of donkeys [25] and mules [107], the latter two with a capacity to transport pronouncedly higher weights of goods [111]. Such a fascioliasis-spreading capacity poses a problem for the implementation of a One Health initiative, because pack animals may give rise to movements of the parasite and the vector from one part to another of the zone selected for control intervention, or the introduction of the parasite and/or the vector from outside into that zone. In the case of llamas, pack animals may contribute to the geographical spread of the lymnaeid snails by passively transporting them in mud attached to their hooves.

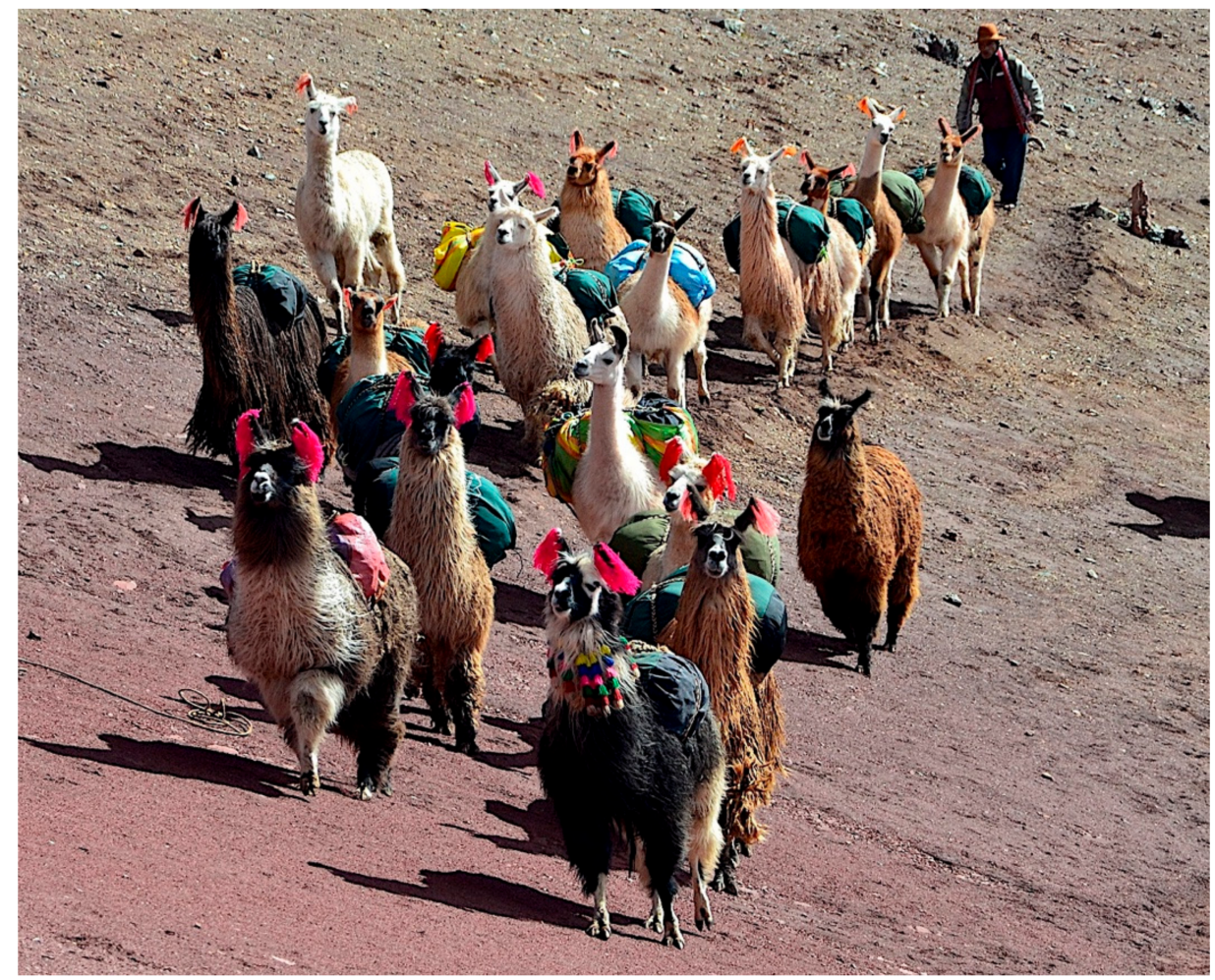

Figure 8. A high altitude Andean caravan of "llamas cargueras" used as pack animals. Note the relatively small packages transported by each animal (compared to the higher weight transporting capacity by donkeys and mules). Slightly modified from a photograph by Andean Lodges, May 2018, freely available from Wikimedia Commons under license of Creative Commons AtribuciónCompartirIgual 4.0 Internacional (CC BY-SA 4.0), https:/ / creativecommons.org/licenses/by-sa/4.0/ deed.es, accessed on 2 July 2021.

Author Contributions: Conceptualization, S.M.-C., R.A., M.A.V. and M.D.B.; methodology, M.M.C., I.R.F., M.C.F. and P.A.; software, M.A.V.; validation, S.M.-C., M.A.V. and M.D.B.; formal analysis, S.M.C., M.M.C., I.R.F., P.B., M.A.V. and M.D.B.; investigation, S.M.-C., M.M.C., I.R.F., R.A., P.B., M.C.F., P.A., M.A.V. and M.D.B.; resources, M.M.C. and R.A.; writing-original draft preparation, S.M.-C.; writing-review and editing, S.M.-C., M.M.C., A.J.M., R.A., P.B., M.A.V. and M.D.B.; visualization, S.M.-C., M.A.V. and M.D.B.; supervision, S.M.-C.; project administration, S.M.-C., A.J.M. and R.A.; funding acquisition, S.M.-C., M.A.V. and M.D.B. All authors have read and agreed to the published version of the manuscript.

Funding: This research was funded by Project No. 2017/ACDE/001583 de Innovación para el Desarrollo of the Agencia Española de Cooperación Internacional para el Desarrollo (AECID), Ministry 
of Foreign Affairs and Cooperation, Madrid, Spain; by Project No. RLA5049 of the International Atomic Energy Agency (Animal Production and Health Section, Joint FAO/IAEA Division of Nuclear Techniques in Food and Agriculture, Department of Nuclear Sciences and Applications, IAEA Headquarters Vienna, Austria); by Health Research Project No. PI16/00520, Subprograma Estatal de Generación de Conocimiento de la Acción Estratégica en Salud (AES) y Fondos FEDER, Plan Estatal de Investigación Científica y Técnica y de Innovación, ISCIII-MINECO, Madrid, Spain; by the Red de Investigación de Centros de Enfermedades Tropicales-RICET (Project No. RD16/0027/0023 of the PN de I+D+I, ISCIII-Subdirección General de Redes y Centros de Investigación Cooperativa RETICS), Ministry of Health and Consumption, Madrid; by Project No. 2016/099 of the PROMETEO Program, Programa of Ayudas para Grupos de Investigación de Excelencia, Generalitat Valenciana, Valencia, Spain; Project No. 2017/01 of the V Convocatoria de Proyectos de Cooperación al Desarrollo de la Universidad de Valencia de 2016, Valencia, Spain; and by CIBER Project CB21/13/00056, ISCIII, Ministry of Science and Education, Madrid, Spain. M.M.C. participated in the experimental procedures during her 6-month stay in the Department of Parasitology, Faculty of Pharmacy, University of Valencia, Spain, funded by a fellowship of the Secretaría de Agricultura, Ganadería y Pesca, Argentina.

Institutional Review Board Statement: All experimental research was performed with the approval of the Evaluation of Projects concerning Animal Research at University of Valencia (Organo Habilitado para la Evaluación de Proyectos de Experimentación Animal de la Universidad de Valencia) (A1263 915389140), strictly following the institution's guidelines based on Directive 2010/63/EU. Permission for animal research was additionally obtained from the Servicio de Sanidad y Bienestar Animal, Dirección General de Producción Agraria y Ganadería, Consellería de Presidencia y Agricultura, Pesca, Alimentación y Agua, Generalitat Valenciana, Valencia, Spain (No. 2015/VSC/PEA/00001 tipo 2). Animal ethics guidelines regarding animal care were strictly adhered. In Argentina, studies on llamas were performed after the guidelines and protocol approved by the Instituto Nacional de Tecnologia Agropecuaria (INTA), of the Ministry of Agriculture, Livestock and Fishing, whose members of the Estaciones Experimentales Agropecuarias of both Abra Pampa and Salta personally collaborated in the field surveys. In Bolivia, the study was approved by the Comisión de Etica de la Investigación of the Comité Nacional de Bioética, La Paz (Certificate dated 10 September 2007), Comité de Etica y Bioética de la Facultad de Medicina de la Universidad Mayor de San Andres, UMSA, La Paz-COMETICA (Resolución COMETICA No. 03/2019, dated 23 July 2019), and Comité de Revisión Etica (PAHOERC) of the Pan American Health Organization, PAHO, Washington DC (Dictamen Ref. No. 2018-02-0007, dated 10 September 2019). All investigations were made after permission was obtained from local Aymara community chiefs (jilakatas and mallkus), and with the consent of animal owners. No ethics approval nor consent was needed for snail collections done on public land.

\section{Informed Consent Statement: Not Applicable.}

Data Availability Statement: The datasets generated for this study are available on request to the corresponding author.

Acknowledgments: Studies of this article have been performed within the framework of the Worldwide Initiative of WHO against Human Fascioliasis (WHO Headquarters, Geneva, Switzerland). One Health initiative designed within the official meeting "Reunión de Análisis con Expertos sobre la Situación Actual y Próximos Pasos para el Control de la Fascioliasis en Bolivia", organized by PAHO/WHO in Hotel Camino Real, Calacoto, La Paz, on 10-12 November 2014, with the participation of (i) Ministerio de Salud de Bolivia, (ii) Ministerio de Desarrollo Rural y Tierras de Bolivia, (iii) Servicio Departamental de Salud de La Paz (SEDES La Paz), (iv) representatives of the Aymara communities from the Northern Altiplano endemic area, (v) delegates from Perú, (vi) experts and advisers of the Programa Regional de Enfermedades Infecciosas Desatendidas of PAHO/WHO, and from the "WHO Collaborating Centre on Fascioliasis and its Snail Vectors of Valencia, and (vii) other foreign experts. The authors acknowledge the facilities provided and the collaboration received from the following organisms, institutions, and centers, as well as their respective representatives or directors: (i) in Argentina: Estación Experimental de Altura Abra Pampa, Abra Pampa, Jujuy; Estación Experimental Agropecuaria Salta, Salta; and Estación Experimental Agropecuaria Rafaela, Rafaela, Santa Fé; Romualdo Suarez and family, owners of the llamas' herd studied in Quichagua, are greatly acknowledged; Ing. Hugo Eduardo Lamas, from Abra Pampa, Jujuy, contributed photographs of "llamas cargueras". (ii) in Bolivia: Servicio Departamental de Salud La Paz (SEDES La Paz); Unidad de Epidemiología of the Bolivian Ministry of Health, La Paz; Office of the Pan American 
Health Organization in La Paz; Dirección Nacional de Producción Pecuaria and the Instituto Nacional de Biología Animal of Chasquipampa-Calacoto both of the Ministerio de Asuntos Campesinos y Agropecuarios (M.A.C.A.) in La Paz; and Granja de Mejoramiento Ganadero de Kallutaca related to the Programa de Fomento Lechero of the Corporación Regional de Desarrollo de La Paz (CORDEPAZ, El Alto).

Conflicts of Interest: The authors declare no conflict of interest. The funders had no role in the design of the study; in the collection, analyses, or interpretation of data; in the writing of the manuscript; or in the decision to publish the results.

\section{References}

1. Schweizer, G.; Braun, U.; Deplazes, P.; Torgerson, P.R. Estimating the financial losses due the bovine fasciolosis in Switzerland. Vet. Rec. 2005, 157, 188-193. [CrossRef]

2. Mazeri, S.; Rydevik, G.; Handel, I.; Bronsvoort, B.M.; de Sargison, C.N. Estimation of the impact of Fasciola hepatica infection on time taken for UK beef cattle to reach slaughter weight. Sci. Rep. 2017, 7, 7319. [CrossRef]

3. Espinoza, J.R.; Terashima, A.; Herrera-Velit, P.; Marcos, L.A. Fasciolosis humana y animal en el Perú: Impacto en la economía de las zonas endémicas. Rev. Peru. Med. Exp. Salud Públ. 2010, 27, 604-612. [CrossRef]

4. Copeman, D.B.; Copland, R.S. Importance and potential impact of liver fluke in cattle and buffalo. In Overcoming Liver Fluke as a Constraint to Ruminant Production in South-East Asia; Gray, G.D., Copland, R.S., Copeman, D.B., Eds.; Australian Centre for International Agricultural Research: Canberra, Australia, 2008; Volume 133, pp. 21-36.

5. Mas-Coma, S.; Agramunt, V.H.; Valero, M.A. Neurological and ocular fascioliasis in humans. Adv. Parasitol. 2014, 84, 27-149.

6. Valero, M.A.; Bargues, M.D.; Khoubbane, M.; Artigas, P.; Quesada, C.; Berinde, L.; Ubeira, F.M.; Mezo, M.; Hernandez, J.L.; Agramunt, V.H.; et al. Higher physiopathogenicity by Fasciola gigantica than by the genetically close F. hepatica: Experimental long-term follow-up of biochemical markers. Trans. R. Soc. Trop. Med. Hyg. 2016, 110, 55-66. [CrossRef]

7. Gonzalez-Miguel, J.; Valero, M.A.; Reguera-Gomez, M.; Mas-Bargues, C.; Bargues, M.D.; Simon-Martin, F.; Mas-Coma, S. Numerous Fasciola plasminogen-binding proteins may underlie blood-brain barrier leakage and explain neurological disorder complexity and heterogeneity in the acute and chronic phases of human fascioliasis. Parasitology 2019, 146, 284-298. [CrossRef]

8. Rondelaud, D.; Dreyfuss, G.; Vignoles, P. Clinical and biological abnormalities in patients after fasciolosis treatment. Med. Mal. Infect. 2006, 36, 466-468. [CrossRef] [PubMed]

9. Chen, M.G.; Mott, K.E. Progress in assessment of morbidity due to Fasciola hepatica infection: A review of recent literature. Trop. Dis. Bull. 1990, 87, R1-R38.

10. Mas-Coma, S.; Bargues, M.D.; Valero, M.A. Diagnosis of human fascioliasis by stool and blood techniques: Update for the present global scenario. Parasitology 2014, 141, 1918-1946. [CrossRef] [PubMed]

11. Girones, N.; Valero, M.A.; Garcia-Bodelon, M.A.; Chico-Calero, M.I.; Punzon, C.; Fresno, M.; Mas-Coma, S. Immune suppression in advanced chronic fascioliasis: An experimental study in a rat model. J. Infect. Dis. 2007, 195, 1504-1512. [CrossRef]

12. Esteban, J.G.; Flores, A.; Angles, R.; Strauss, W.; Aguirre, C.; Mas-Coma, S. A population-based coprological study of human fascioliasis in a hyperendemic area of the Bolivian Altiplano. Trop. Med. Int. Health 1997, 2, 695-699. [CrossRef]

13. Gonzalez, L.C.; Esteban, J.G.; Bargues, M.D.; Valero, M.A.; Ortiz, P.; Naquira, C.; Mas-Coma, S. Hyperendemic human fascioliasis in Andean valleys: An altitudinal transect analysis in children of Cajamarca province, Peru. Acta Trop. 2011, 120, 119-129. [CrossRef]

14. Brady, M.T.; O’Neill, S.M.; Dalton, J.P.; Mills, K.H. Fasciola hepatica suppresses a protective Th1 response against Bordetella pertussis. Infect. Immun. 1999, 67, 5372-5378. [CrossRef] [PubMed]

15. Valero, M.A.; Navarro, M.; Garcia-Bodelon, M.A.; Marcilla, A.; Morales, M.; Garcia, J.E.; Hernandez, J.L.; Mas-Coma, S. High risk of bacterobilia in advanced experimental chronic fasciolosis. Acta Trop. 2006, 100, 17-23. [CrossRef]

16. Ollerenshaw, C.B. The ecology of the liver fluke (Fasciola hepatica). Vet. Rec. 1959, 71, 957-965.

17. Afshan, K.; Fortes-Lima, C.A.; Artigas, P.; Valero, M.A.; Qayyum, M.; Mas-Coma, S. Impact of climate change and man-made irrigation systems on the transmission risk, long-term trend and seasonality of human and animal fascioliasis in Pakistan. Geospat. Health 2014, 8, 317-334. [CrossRef]

18. Mas-Coma, S.; Valero, M.A.; Bargues, M.D. Fasciola, lymnaeids and human fascioliasis, with a global overview on disease transmission, epidemiology, evolutionary genetics, molecular epidemiology and control. Adv. Parasitol. 2009, 69, 41-146.

19. De, N.V.; Le, T.H.; Agramunt, V.H.; Mas-Coma, S. Early postnatal and preschool age infection by Fasciola spp.: Report of five cases from Vietnam and worldwide review. Am. J. Trop. Med. Hyg. 2020, 103, 1578-1589. [CrossRef]

20. Mas-Coma, S. Human fascioliasis emergence risks in developed countries: From individual patients and small epidemics to climate and global change impacts. Enf. Emerg. Microbiol. Clín. 2020, 38, 253-256. [CrossRef] [PubMed]

21. World Health Organization. Sustaining the Drive to Overcome the Global Impact of Neglected Tropical Diseases; Department of Control of Neglected Tropical Diseases, World Health Organization: Geneva, Switzerland, 2013; p. 128.

22. Gandhi, P.; Schmitt, E.K.; Chen, C.W.; Samantray, S.; Venishetty, V.K.; Hughes, D. Triclabendazole in the treatment of human fascioliasis: A review. Trans. R. Soc. Trop. Med. Hyg. 2019, 113, 797-804. [CrossRef] [PubMed] 
23. World Health Organization. Ending the Neglect to Attain the Sustainable Development Goals. A Road Map for Neglected Tropical Diseases 2021-2030; World Health Organization: Geneva, Switzerland, 2020; p. 47. Available online: https://www.who.int/neglected_ diseases /Ending-the-neglect-to-attain-the-SDGs--NTD-Roadmap.pdf (accessed on 23 July 2020).

24. Mas-Coma, S.; Buchon, P.; Funatsu, I.R.; Angles, R.; Artigas, P.; Valero, M.A.; Bargues, M.D. Sheep and cattle reservoirs in the highest human fascioliasis hyperendemic area: Experimental transmission capacity, field epidemiology and control within a One Health initiative in Bolivia. Front. Vet. Sci. 2020, 7, 583204. [CrossRef] [PubMed]

25. Mas-Coma, S.; Buchon, P.; Funatsu, I.R.; Angles, R.; Mas-Bargues, C.; Artigas, P.; Valero, M.A.; Bargues, M.D. Donkey fascioliasis within a One Health control action: Transmission capacity, field epidemiology, and reservoir role in a human hyperendemic area. Front. Vet. Sci. 2020, 7, 591384. [CrossRef] [PubMed]

26. Mas-Coma, S.; Funatsu, I.R.; Angles, R.; Buchon, P.; Mas-Bargues, C.; Artigas, P.; Valero, M.A.; Bargues, M.D. Domestic pig prioritized in one health action against fascioliasis in human endemic areas: Experimental assessment of transmission capacity and epidemiological evaluation of reservoir role. ONE Health 2021, 13, 100249. [CrossRef] [PubMed]

27. Mas-Coma, S.; Bargues, M.D.; Valero, M.A. Human fascioliasis infection sources, their diversity, incidence factors, analytical methods and prevention measures. Parasitology 2018, 145, 1665-1699. [CrossRef]

28. Bargues, M.D.; Artigas, P.; Angles, R.; Osca, D.; Duran, P.; Buchon, P.; Gonzales-Pomar, R.K.; Pinto-Mendieta, J.; Mas-Coma, S. Genetic uniformity, geographical spread and anthropogenic habitat modifications of lymnaeid vectors found in a One Health initiative in the highest human fascioliasis hyperendemic of the Bolivian Altiplano. Parasit Vectors 2020, 13, 171. [CrossRef] [PubMed]

29. Bargues, M.D.; Angles, R.; Coello, J.; Artigas, P.; Funatsu, I.R.; Cuervo, P.F.; Buchon, P.; Mas-Coma, S. One Health initiative in the Bolivian Altiplano human fascioliasis hyperendemic area: Lymnaeid biology, population dynamics, microecology and climatic factor influences. Braz. J. Vet. Parasitol. 2021, 30, e025620. [CrossRef]

30. Fassi-Fehri, M.M. Las enfermedades de los camélidos. Rev. Sci. Tech. Off. Int. Epiz. 1987, 6, 355-373.

31. Malandrini, J.B.; Carnevale, S.; Velazquez, J.; Soria, C.C. Diagnóstico de Fasciola hepatica con la técnica de ELISA en el Departamento de Tinogasta. Ciencia 2009, 4, 143-151.

32. Mera y Sierra, R.; Agramunt, V.H.; Cuervo, P.; Mas-Coma, S. Human fascioliasis in Argentina: Retrospective overview, critical analysis and baseline for future research. Parasit. Vectors 2011, 4, 104. [CrossRef]

33. Bargues, M.D.; Malandrini, J.B.; Artigas, P.; Soria, C.C.; Velasquez, J.N.; Carnevale, S.; Mateo, L.; Khoubbane, M.; Mas-Coma, S. Human fascioliasis endemic areas in Argentina: Multigene characterisation of the lymnaeid vectors and climatic-environmental assessment of the transmission pattern. Parasit. Vectors 2016, 9, 306. [CrossRef] [PubMed]

34. Cafrune, M.M.; Rebuffi, G.E.; Cabrera, R.H.; Aguirre, D.H. Fasciola hepatica en llamas (Lama glama) de la puna argentina. Vet. Arg. 1996, 13, 570-574.

35. Cafrune, M.M.; Rebuffi, G.E.; Gaido, A.B.; Aguirre, D.H. Fasciola hepatica in Semi-Captive Vicuñas (Vicugna vicugna) in North West Argentina. Vet. Rec. 1996, 139, 97. [CrossRef] [PubMed]

36. Cafrune, M.M.; Aguirre, D.H.; Freytes, I. Fasciolosis en vicuñas (Vicugna vicugna) en semi-cautiverio de Molinos, Salta, Argentina, con notas de otros helmintos en este hospedador. Vet. Arg. 2004, 21, 513-520.

37. Olaechea, F.V.; Abad, M. An outbreak of fascioliasis in semicaptive guanacos (Lama guanicoe) in Patagonia (Argentina). First report. In XX International Conference of the World Association for the Advancement of Veterinary Parasitology; WAAVP: Christchurch, New Zealand, 2005.

38. Issia, L.; Ovejero, R.; Carmanchahi, P.; Pietrokovsky, S.; Wisnivesky-Colli, C. Primer registro de Fasciola hepatica en guanacos silvestres de Mendoza, Argentina. V Congreso Latinoamericano de Especialistas en Pequeños Rumiantes y Camélidos Sudamericanos. Mendoza 2007, 1-2. Available online: www.produccion-animal.com.ar (accessed on 23 January 2021).

39. Apt, W.; Aguilera, X.; Vega, F.; Zulantay, I.; Retamal, C.; Apt, P.; Sandoval, J. Fascioliasis en la población rural de las provincias de Curico, Talca y Linares. Rev. Méd. Chile 1992, 120, 621-626.

40. Artigas, P.; Bargues, M.D.; Mera y Sierra, R.; Agramunt, V.H.; Mas-Coma, S. Characterisation of fascioliasis lymnaeid intermediate hosts from Chile by DNA sequencing, with emphasis on Lymnaea viator and Galba truncatula. Acta Trop. 2011, 120, $245-257$. [CrossRef]

41. Alcaino, H.; Gorman, T. Parásitos de los animales domésticos en Chile. Parasitol. Día 1999, 23, 33-41. [CrossRef]

42. Hillyer, G.V.; Soler de Galanes, M.; Rodriguez-Perez, J.; Bjorland, J.; Silva de Lagrava, M.; Ramirez Guzman, S.; Bryan, R.T. Use of the Falcon Assay Screening Test-Enzyme-Linked Immunosorbent Assay (FAST-ELISA) and the Enzyme-Linked Immunoelectrotransfer Blot (EITB) to determine the prevalence of human fascioliasis in the Bolivian Altiplano. Am. J. Trop. Med. Hyg. 1992, 46, 603-609. [CrossRef]

43. Mas-Coma, S.; Angles, R.; Esteban, J.G.; Bargues, M.D.; Buchon, P.; Franken, M.; Strauss, W. The Northern Bolivian Altiplano: A region highly endemic for human fascioliasis. Trop. Med. Int. Health 1999, 4, 454-467. [CrossRef] [PubMed]

44. Ueno, H.; Arandia, C.R.; Morales, L.G.; Medina, M.G. Fascioliasis of livestock and snail host for Fasciola in Altiplano region of Bolivia. Natl. Inst. Anim. Hlth. Quart. 1975, 15, 61-67.

45. Mas-Coma, S.; Angles, R.; Strauss, W.; Esteban, J.G.; Oviedo, J.A.; Buchon, P. Human fasciolasis in Bolivia: A general analysis and a critical review of existing data. Res. Rev. Parasitol. 1995, 55, 73-93. 
46. Raymundo, L.A.M.; Maco Flores, V.; Terashima, A.; Samalvides, F.; Miranda, E.; Tantalean, M.; Espinoza, J.R.; Gotuzzo, E. Hiperendemicidad de fasciolosis humana en el Valle del Mantaro, Perú: Factores de riesgo de la infección por Fasciola hepatica. Rev. Gastroenterol. Perú 2004, 24, 158-164.

47. Valencia, N.; Pariona, A.; Huaman, M.; Miranda, F.; Quintanilla, S.; Gonzales, A. Seroprevalencia de fasciolosis en escolares y en ganado vacuno en la provincia de Huancavelica, Perú. Rev. Peru. Med. Exp. Salud Publ. 2005, 22, 96-102.

48. Espinoza, J.R.; Maco, V.; Marcos, L.; Saez, S.; Neyra, V.; Terashima, A.; Samalvides, F.; Gotuzzo, E.; Chavarry, E.; Huaman, C.; et al. Evaluation of Fas2-ELISA for the serological detection of Fasciola hepatica infection in humans. Am. J. Trop. Med. Hyg. 2007, 76, 977-982. [CrossRef]

49. Valero, M.A.; Perez-Crespo, I.; Khoubbane, M.; Artigas, P.; Panova, M.; Ortiz, P.; Maco, V.; Espinoza, J.R.; Mas-Coma, S. Fasciola hepatica phenotypic characterisation in Andean human endemic areas: Valley versus altiplanic patterns analysed in liver flukes from sheep from Cajamarca and Mantaro, Peru. Infect. Genet. Evol. 2012, 12, 403-410. [CrossRef]

50. Valero, M.A.; Periago, M.V.; Perez-Crespo, I.; Angles, R.; Villegas, F.; Aguirre, C.; Strauss, W.; Espinoza, J.R.; Herrera, P.; Terashima, A.; et al. Field evaluation of a coproantigen detection test for fascioliasis diagnosis and surveillance in human hyperendemic areas of Andean countries. PLoS Negl. Trop. Dis. 2012, 6, e1812. [CrossRef]

51. Lopez, M.; White, A.C., Jr.; Cabada, M.M. Burden of Fasciola hepatica infection among children from Paucartambo in Cusco, Peru. Am. J. Trop. Med. Hyg. 2012, 86, 481-485. [CrossRef]

52. Bargues, M.D.; Artigas, P.; Khoubbane, M.; Ortiz, P.; Naquira, C.; Mas-Coma, S. Molecular characterisation of Galba truncatula, Lymnaea neotropica and L. schirazensis from Cajamarca, Peru and their potential role in transmission of human and animal fascioliasis. Parasit. Vectors 2012, 5, 174. [CrossRef]

53. Bardales-Valdivia, J.N.; Bargues, M.D.; Hoban-Vergara, C.; Bardales-Bardales, C.; Goicoechea-Portal, C.; Bazan-Zurita, H.; Del Valle-Mendoza, J.; Ortiz, P.; Mas-Coma, S. Spread of the fascioliasis endemic area assessed by seasonal follow-up of rRNA ITS-2 sequenced lymnaeid populations in Cajamarca, Peru. One Health 2021, 13, 100265. [CrossRef]

54. Esteban, J.G.; Gonzalez, C.; Bargues, M.D.; Angles, R.; Sanchez, C.; Naquira, C.; Mas-Coma, S. High fascioliasis infection in children linked to a man-made irrigation zone in Peru. Trop. Med. Int. Health 2002, 7, 339-348. [CrossRef]

55. Leguia, G. The epidemiology and economic impact of llama parasites. Parasitol. Today 1991, 7, 54-56. [CrossRef]

56. Flores, B.; Pinedo, R.; Suárez, F.; Angelats, R.; Chávez, A. Prevalencia de fasciolosis en llamas y alpacas en dos comunidades rurales de Jauja, Peru. Rev. Investig. Vet. Perú 2014, 25, 284-292. [CrossRef]

57. Hernandez, J.; Condorena, N. Fasciola hepatica en higado de alpaca. Rev. Fac. Med. Vet. Lima 1967, 21, 138-139.

58. Leguia, G. Acute and subacute fasciolosis of alpacas and treatment with triclabendazole. Trop. Anim. Health Prod. 1997, $29,31-32$.

59. Neyra, V.; Chavarry, E.; Espinoza, J.R. Cysteine proteinases Fas1 and Fas2 are diagnostic markers of Fasciola hepatica infection in alpacas (Lama pacos). Vet. Parasitol. 2002, 105, 21-32. [CrossRef]

60. Del Pizarro, R.P.; Puray, N. Huevos de Fasciola hepatica en heces de vicuña ((Vicugna vicugna) en Tullpacancha Huancavelica-Perú. Enfoque Veterinario 2014, 1, 1-5.

61. Samamé, L.M.; Chávez, A.; Pinedo, R. Fasciolosis en vicuñas (Vicugna vicugna) de la Sierra Central del Perú. Rev. Investig. Vet. Perú 2016, 27, 137-144. [CrossRef]

62. Kühne, G.I. Parásitos diagnosticados en el decenio 1976-198 en la Unidad Regional de Investigación en Sanidad Animal del Noroeste Argentino. I. Helmintos y protozoarios. Rev. Investig. Agropec. INTA 1986, 21, 73-79.

63. Boray, J.C.; Enigk, K. Laboratory studies on the survival and infectivity of Fasciola hepatica and F. gigantica metacercariae. Zeitsch. Tropenmed. Parasitol. 1964, 15, 324-331.

64. Bargues, M.D.; Mangold, A.J.; Muñoz-Antoli, C.; Pointier, J.P.; Mas-Coma, S. SSU rDNA characterization of lymnaeid snails transmitting human fascioliasis in South and Central America. J. Parasitol. 1997, 83, 1086-1092. [CrossRef] [PubMed]

65. Bargues, M.D.; Artigas, P.; Mera y Sierra, R.; Pointier, J.P.; Mas-Coma, S. Characterisation of Lymnaea cubensis, L. viatrix and L. neotropica n. sp., the main vectors of Fasciola hepatica in Latin America, by analysis of their ribosomal and mitochondrial DNA. Ann. Trop. Med. Parasitol. 2007, 101, 621-641. [CrossRef]

66. Bargues, M.D.; Gayo, V.; Sanchis, J.; Artigas, P.; Khoubbane, M.; Birriel, S.; Mas-Coma, S. DNA multigene characterization of Fasciola hepatica and Lymnaea neotropica and its fascioliasis transmission capacity in Uruguay, with historical correlation, human report review and infection risk analysis. PLoS Negl. Trop. Dis. 2017, 11, e0005352. [CrossRef]

67. Bargues, M.D.; Artigas, P.; Khoubbane, M.; Flores, R.; Glöer, P.; Rojas-Garcia, R.; Ashrafi, K.; Falkner, G.; Mas-Coma, S. Lymnaea schirazensis, an overlooked snail distorting fascioliasis data: Genotype, phenotype, ecology, worldwide spread, susceptibility, applicability. PLoS ONE 2011, 6, e24567. [CrossRef]

68. Valero, M.A.; Panova, M.; Comes, A.M.; Fons, R.; Mas-Coma, S. Patterns in size and shedding of Fasciola hepatica eggs by naturally and experimentally infected murid rodents. J. Parasitol. 2002, 88, 308-313. [CrossRef]

69. Valero, M.A.; Mas-Coma, S. Comparative infectivity of Fasciola hepatica metacercariae from isolates of the main and secondary reservoir animal host species in the Bolivian Altiplano high human endemic region. Folia Parasitol. 2000, 47, 17-22. [CrossRef] [PubMed]

70. Valero, M.A.; Girones, N.; Garcia-Bodelon, M.A.; Periago, M.V.; Chico-Calero, I.; Khoubbane, M.; Fresno, M.; Mas-Coma, S. Anaemia in advanced chronic fasciolosis. Acta Trop. 2008, 108, 35-43. [CrossRef] [PubMed]

71. Dwinger, R.H.; Le Riche, P.D.; Kühne, G.I. Fascioliasis in beef cattle in North-west Argentina. Trop. Anim. Health Prod. 1982, 14, 167-171. [CrossRef] [PubMed] 
72. Viñabal, A.E.; Aguirre, D.H. Modificación de una técnica coprológica para el diagnóstico de Fasciola hepatica. In Memorias de la $8^{a}$ Reunión Anual de la Asociación Argentina de Veterinarios de Laboratorio de Diagnóstico; AAVLD: Corrientes, Argentina, November 1992; p. 64.

73. Dennis, W.R.; Stone, W.M.; Swanson, L.E. A new laboratory and field diagnostic test for fluke ova in feces. J. Am. Vet. Med. Ass. 1954, 124, 47-50.

74. Cheriuyot, H.K.; Jordan, H.E. Potential for the spread of Fasciola hepatica in cattle in Oklahoma. J. Am. Vet. Med. Ass. 1990, 196, 1090-1094.

75. Valero, M.A.; Panova, M.; Mas-Coma, S. Phenotypic analysis of adults and eggs of Fasciola hepatica by computer image analysis system. J. Helminthol. 2005, 79, 217-225. [CrossRef]

76. Anderson, D.E.; Environmental Impact of Camelids. Big Meadow Creek Farm, Troy. 2009. Available online: http: / / bigmeadowcreekalpacas.com/About\%20Alpacas/environmentalimpact.htm (accessed on 16 January 2021).

77. Adam, K.; Adam, E.; Alpaca and Llama Beans. Serendipity Farm and Sanctuary, Lanark. 2014. Available online: http: / / www.serendipityalpacas.ca/pages/3755/alpaca--llama-beans (accessed on 16 January 2021).

78. Fairweather, I.; Brennan, G.P.; Hanna, R.E.B.; Robinson, M.W.; Skuce, P.J. Drug resistance in liver flukes. Int. J. Parasitol. Drugs Drug Res. 2020, 12, 39-59. [CrossRef]

79. Wilson, R.A.; Smith, G.; Thomas, M.R. Fascioliasis. In The Population Dynamics of Infectious Diseases: Theory and Applications, Anderson, R.M., Ed.; Chapman and Hall: New York, NY, USA, 1982; pp. 262-319.

80. Diez-Baños, M.A.; Rojo-Vázquez, F.A. Influencia de la temperatura en el desarrollo de los huevos de Fasciola hepatica. An. Fac. Vet. León 1976, 22, 65-75.

81. Kendall, S.B. Nutritional factors affecting the rate of development of Fasciola hepatica in Limnaea truncatula. J. Helminthol. 1993, 23, 179-190. [CrossRef] [PubMed]

82. Rondelaud, D. Variabilité interpopulationelle de l'infestation fasciolenne chez le mollusque Lymnaea truncatula Müller. Influence du contact préalable de la population avec le parasite. Bull. Soc. Zool. Franc. 1993, 118, 185-193.

83. Vignoles, P.; Dreyfuss, G.; Rondelaud, D. Larval development of Fasciola hepatica in experimental infections: Variations with populations of Lymnaea truncatula. J. Helminthol. 2002, 76, 179-183. [CrossRef] [PubMed]

84. Roberts, W.E. Studies on the life-cycle of Fasciola hepatica (Linnaeus) and of its snail host Limnaea (Galba) truncatula (Müller) in the field and under controlled conditions in the laboratory. Ann. Trop. Med. Parasitol. 1950, 44, 187-206. [CrossRef] [PubMed]

85. Rondelaud, D.; Barthe, D. Les générations rédiennes de Fasciola hepatica L. Premières observations chez des Limnées tronquées en fin de cycle parasitaire. Bull. Soc. Franç. Parasitol. 1986, 4, 29-38.

86. Rondelaud, D.; Dreyfuss, G. Fasciola hepatica: The influence of the definitive host on the characteristics of the infection in the snail Lymnaea truncatula. Parasite 1995, 2, 275-280. [CrossRef]

87. Mas-Coma, S.; Funatsu, I.R.; Bargues, M.D. Fasciola hepatica and lymnaeid snails occurring at very high altitude in South America. Parasitology 2001, 123, S115-S127. [CrossRef]

88. Dreyfuss, G.; Rondelaud, D. Fasciola hepatica: A study of the shedding of cercariae from Lymnaea truncatula raised under constant conditions of temperature and photoperiod. Parasite 1994, 4, 401-404. [CrossRef]

89. Audousset, J.C.; Rondelaud, D.; Dreyfuss, G.; Vareille-Morel, C. Les émissions cercariennes de Fasciola hepatica L. chez le mollusque Lymnaea truncatula Müller. A propos de quelques observations chronobiologiques. Bull. Soc. Franç. Parasitol. 1989, 7, 217-224.

90. Hodasi, J.K.M. The output of cercariae of Fasciola hepatica by Lymnaea truncatula and the distribution of metacercariae on grass. Parasitology 1972, 63, 431-456. [CrossRef]

91. Bargues, M.D.; Oviedo, J.A.; Funatsu, I.R.; Rodriguez, A.; Mas-Coma, S. Survival of lymnaeid snails from the Bolivian Northern Altiplano after the parasitation by different Bolivian isolates of Fasciola hepatica (Linnaeus, 1758) (Trematoda: Fasciolidae). In Unitas Malacologica; Guerra, A., Rolán, E., Rocha, F., Eds.; Instituto de Investigaciones Marinas, CSIC: Vigo, Spain, 1995; pp. 443-445.

92. Kimura, S.; Shimizu, A. Studies on the survival and infectivity of Fasciola gigantica metacercariae. Sci. Rep. Fac. Agr. Kobe Univ. 1979, 13, 347-349.

93. Leguía, G. Enfermedades Parasitarias de Camélidos Sudamericanos; Del Mar: Lima, Peru, 1999; p. 190.

94. Rickard, L.G. Development and application of a dot-ELISA test for the detection of serum antibodies to Fasciola hepatica antigens in llamas. Vet. Parasitol. 1995, 58, 9-15. [CrossRef]

95. Cafrune, M.M.; Marin, R.E.; Auad, G.T.; Aguirre, D.H. Coprología parasitaria en llamas (Lama glama) de la Puna de Jujuy, Argentina. In IV Congr. Mund. Camélidos; Oliveira, D., Miragaya, M., Puig, S., Eds.; Resumenes y Trabajos: Santa María, Argentina, 2006; p. 44.

96. Cafrune, M.M.; Romero, S.R.; Rigalt, F.A.; Marin, R.E.; Aguirre, D.H. Coprological prevalence of gastrointestinal helminths in South American camelids of Northwest Argentina. In Proceedings of the 23th International Conference of the World Association for the Advancement of Veterinary Parasitology (WAAVP), Buenos Aires, Argentina, 21-25 August 2011; p. 20.

97. Lorini, J.; Liberman, M. El clima de la provincia Aroma del departamento de La Paz, Bolivia. Ecología Bolivia 1983, 4, 19-29. 
98. Mina, Q.J.C.; Santa Cruz, G.S.; Guzman, C.J. Prevalencia de Fasciola hepatica en Llamas Faenadas en el Matadero de Turco (Provincia Sajama, Departamento de Oruro); Facultad de Ciencias Veterinarias, Universidad Autónoma Gabriel René Moreno; Santa Cruz de la Sierra, Bolivia. 2010, pp. 1-33. Available online: https: / docplayer.es $/$ docview $/ 77 / 75317131 / \#$ file $=/$ storage $/ 77$ /75317131/75317131.pdf (accessed on 23 January 2021).

99. Rickard, L.R.; Foreyt, W.J. Experimental fascioliasis in llamas. J. Helminthol. Soc. Wash. 1992, 59, $140-144$.

100. Duff, J.P.; Maxwell, A.J.; Claxton, J.R. Chronic and fatal fascioliasis in llamas in the UK. Vet. Rec. 1999, 145, 315-316. [CrossRef] [PubMed]

101. Valero, M.A.; Darce, N.A.; Panova, M.; Mas-Coma, S. Relationships between host species and morphometric patterns in Fasciola hepatica adults and eggs from the Northern Bolivian Altiplano hyperendemic region. Vet. Parasitol. 2001, 102, 85-100. [CrossRef]

102. Valero, M.A.; Perez-Crespo, I.; Chillon-Marinas, C.; Khoubbane, M.; Quesada, C.; Reguera-Gomez, M.; Mas-Coma, S.; Fresno, M.; Girones, N. Fasciola hepatica reinfection potentiates a mixed Th1/Th2/Th17/Treg response and correlates with the clinical phenotypes of anemia. PLoS ONE 2017, 12, e0173456. [CrossRef] [PubMed]

103. Valero, M.A.; Girones, N.; Reguera-Gomez, M.; Perez-Crespo, I.; Lopez-Garcia, M.P.; Quesada, C.; Bargues, M.D.; Fresno, M.; Mas-Coma, S. Impact of fascioliasis reinfection on Fasciola hepatica egg shedding: Relationship with the immune-regulatory response. Acta Trop. 2020, 209, 105518. [CrossRef] [PubMed]

104. Boray, J.C. Experimental fascioliasis in Australia. Adv. Parasitol. 1969, 7, 95-210.

105. Gunsser, I.; Hänichen, T.; Maier, J. Liver fluke infestation in New World camelids. Parasitology, pathology, clinical findings and therapy. Tierarztl. Prax. Ausg. G. Grosstiere Nutztiere 1999, 27, 187-192. (In German)

106. Cornick, J.L. Gastric squamous cell carcinoma and fascioliasis in a llama. Cornell Vet. 1988, 78, 235-241. [PubMed]

107. Mera y Sierra, R.; Neira, G.; Bargues, M.D.; Cuervo, P.F.; Artigas, P.; Logarzo, L.; Cortiñas, G.; Ibaceta, D.E.J.; Lopez Garrido, A.; Bisutti, E.; et al. Equines as reservoirs of human fascioliasis: Transmission capacity, epidemiology and pathogenicity in Fasciola hepatica infected mules. J. Helminthol. 2020, 94, e189. [CrossRef] [PubMed]

108. Hamir, A.N.; Smith, B.B. Severe biliary hyperplasia associated with liver fluke infestation in an adult alpaca. Vet. Pathol. 2002, 39, 592-594. [CrossRef] [PubMed]

109. Barreto, T.; Alfonso, Y.; Lafaye, P.; García Lazaro, M.d.P.; Agueda Perez, L.; Herrera-Velit, P.; Espinoza, J.R. Anticuerpos de cadena única de alpaca para la detección de antígenos de Fasciola hepatica. Rev. Peru. Med. Exp. Salud Publica 2018, 35, 573-580. [CrossRef] [PubMed]

110. Ogrzewalska, M.; Nieri-Bastos, F.A.; Marcili, A.; Nava, S.; González-Acuña, D.; Muñoz-Leal, S.; Ruiz-Arrondo, I.; Venzal, J.M.; Mangold, A.; Labruna, M.B. A novel spotted fever group Rickettsia infecting Amblyomma parvitarsum (Acari: Ixodidae) in highlands of Argentina and Chile. Ticks Tick Borne Dis. 2016, 7, 439-442. [CrossRef] [PubMed]

111. Mitchell, P. The Donkey in Human History. An. Archaelogical Perspective; Oxford University Press: Oxford, UK, 2018 ; p. 306. 